Japan. J. Med. Sci. Biol., 34, 113-147, 1981

SPECIAL REVIEW

\title{
THE PRESENT STATUS OF PUBLIC HEALTH LABORATORY SYSTEM IN JAPAN WITH SPECIAL REFERENCE TO INFECTIOUS DISEASES
}

\author{
KoomI KANAI \\ The First Department of Bacteriology, National Institute of Health, \\ Kamiosaki, Shinagawa-ku, Tokyo 141
}

(Received February 2, 1981. Accepted April 27, 1981)

\section{CONTENTS}

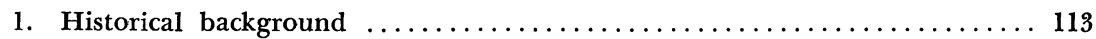

2. The national network of public health laboratory services in microbiology.. 115

3. Prefectural and municipal laboratories $\ldots \ldots \ldots \ldots \ldots \ldots \ldots \ldots \ldots \ldots \ldots \ldots \ldots$

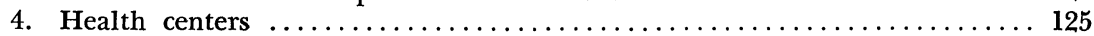

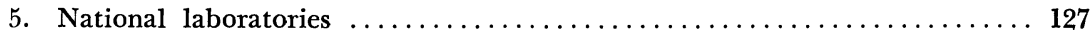

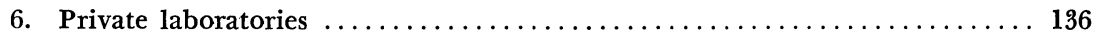

7. The surveillance system for infectious diseases $\ldots \ldots \ldots \ldots \ldots \ldots \ldots \ldots \ldots$ Addenda

1) The legal basis for communicable disease control ............. 145

2) The annual change of notifiable communicable diseases in the past

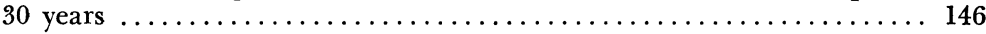

\section{Historical Background}

According to the terminology of World Health Organization (WHO), a public health laboratory is a unit in preventive medicine primarily for identifying and investigating the causative factors of ill health in the community, while a hospital laboratory is a service unit in curative medicine primarily for the diagnosis and management of the individual patient (WHO, 1957, 1962, 1972). These two types of laboratory can be combined into one unit (a health laboratory) as usually seen in developing countries. It has been often stated that the combined type is more economical and functional, saving the doubling of manpower, budget, and facilities, and more efficient in collecting and unifying the wide rage of laboratory information.

In Japan, the public health laboratory system (PHLS) has developed independently of the hospital laboratory system. Since the Meiji era, the health bureau of each prefecture had bacteriological and hygienic chemical laboratories,

金井興美（国立予防衛生研究所 細菌第一部） 
though most of them were very small in scale. Their function was mainly to maintain public peace and order in the whole country, rather than to serve the health of community residents. Prefectural governments were then under the strong nationalistic control by the Ministry of Internal Affairs of the central government (Kodama, 1968).

However, the situation changed when World War II ended in 1945 and the Occupation Forces landed here to introduce a new principle and system of administration. Local autonomy was much more strengthened on the democratic way of thinking. On November 22, 1945, General Headquarters conveyed a memorandum to Japanese Government recommending the improvement of public health and sanitation. In response to this memorandum, the Government started various administrative procedures necessary for this purpose.

The most urgent public health problem in this period was the control of infectious diseases. Tuberculosis was the No. 1 killer, the mortality being more than 200 per 100,000 population. Many acute infectious diseases such as typhoid fever, dysentery, diphtheria, pertussis and others, were prevalent in the whole country. Cholera, typhus and small pox were imported along with repatriation of soldiers and civilians from foreign areas. Under such circumstances, the National Institute of Health (NIH) was founded in 1947 as the central laboratory for the control of infectious diseases.

On the other hand, Health Center Law was revised in 1947 providing laboratory testing work as one of the basic functions of health centers. Therefore, most health centers came to have laboratories where simple tests can be carried out to answer health problems of local residents.

Then, in 1948, a recommendation was given to each prefectural government by the joint names of three bureau directors of the Ministry of Health and Welfare (MHW) to establish a public health laboratory by integrating the hitherto existing bacteriological and hygienic facilities. This recommendation, though without a supporting specific law, was successful in making all prefectures have their own public health laboratories within the succeeding 4 years. Thus, a situation was established to make it possible that the network of laboratories is organized by connecting those at the central, district and peripheral levels. During the two decades, a remarkable change occurred in the social, economic and industrial conditions of the country. The reconstruction and development of the destructed country proceeded far more rapidly than imagined before. Besides, most of acute bacterial infections were brought under control, if not completely. On the other hand, the surveillance of virus diseases became increasingly an important duty of public health laboratories. New types of public health hazards emerged one after another because of increasing environmental pollution. In addition, foodstuff control to meet the changing pattern of food preservation and eating habits became an essential task of PHLS.

In view of this situation, active discussion was stimulated among public health personnels on the problem how to remodel and strengthen the district laboratories so that they can satisfy the changing social needs. Finally, a research 
group headed by Dr. Yanagisawa, then Deputy Director-General of NIH, was organized with the financial support from MHW to review the above discussion. In 1964, a conclusion was drawn to prepare the formal document, which was conveyed to governors of prefectures and municipalities by the name of viceminister of MHW (Notification from the Ministry of Health and Welfare, No. 125, 1964). The recommendation stated the standard level of organization, premises, manpower, functions and equipments which are desirable for satisfactory activities in district public heilth laboratories (DPHL). This administrative procedure appeared to have a definite effect on prefectural governments, because most public health laboratories were then enlarged in the building, manpower, and organization, and became better-equipped sooner or later. In some districts, a separate laboratory specializing in environmental control was established to share the ever increasing amount of workload with the existing public health laboratory. As for the microbiological field, many public health laboratories added virus sections to their organizations.

In 1960, an international seminar on health laboratory services was held on the sponsorship of WHO Regional Office for the Western Pacific in Manila. Dr. Yanagisawa of NIH and Dr. Takabe of MHW were the participants of this meeting. This was the first occasion of this kind, and the second one was held in 1972, again in Manila, which the present author, then Director of Yamanashi Prefectural Institute for Public Health, attended to report the situation of PHLS in Japan. We learned the systematic way of thinking concerning PHLS from these two seminars.

In the meantime, the economical, industrial and technical development was continually so rapid after 1964 on the Vice Minister's Notification, accompanying the marked changes in public health situation. Then, the National Association of District Public Health Laboratories set up a special committee to discuss about the modernization of the planning, organization, and administration of DPHL. The committee was soon enlarged inviting administrative officials of MHW and staff of NIH as members. On the basis of discussion held here, the 2nd Vice-Minister's Notification (No. 173, 1976) was issued on Nov. 10, which played the role of guideline to improve the laboratories to the up-to-date style.

More recently, a new movement started on the agreement among the directors of DPHLs (Dr. Inoue as the representative) and Director-General of NIH (Dr. Murata) to strengthen the liaison between national laboratories and district laboratories, aiming especially at the closer co-operation at technical level and to establish the system for integrating laboratory information in a nation-wide scale.

\section{The National Network of Public Health Laboratory Services in Microbiological Fields}

As stated in the preceding chapter, hospital and public health laboratory systems are separated in Japan unlike the combined type as seen in England 


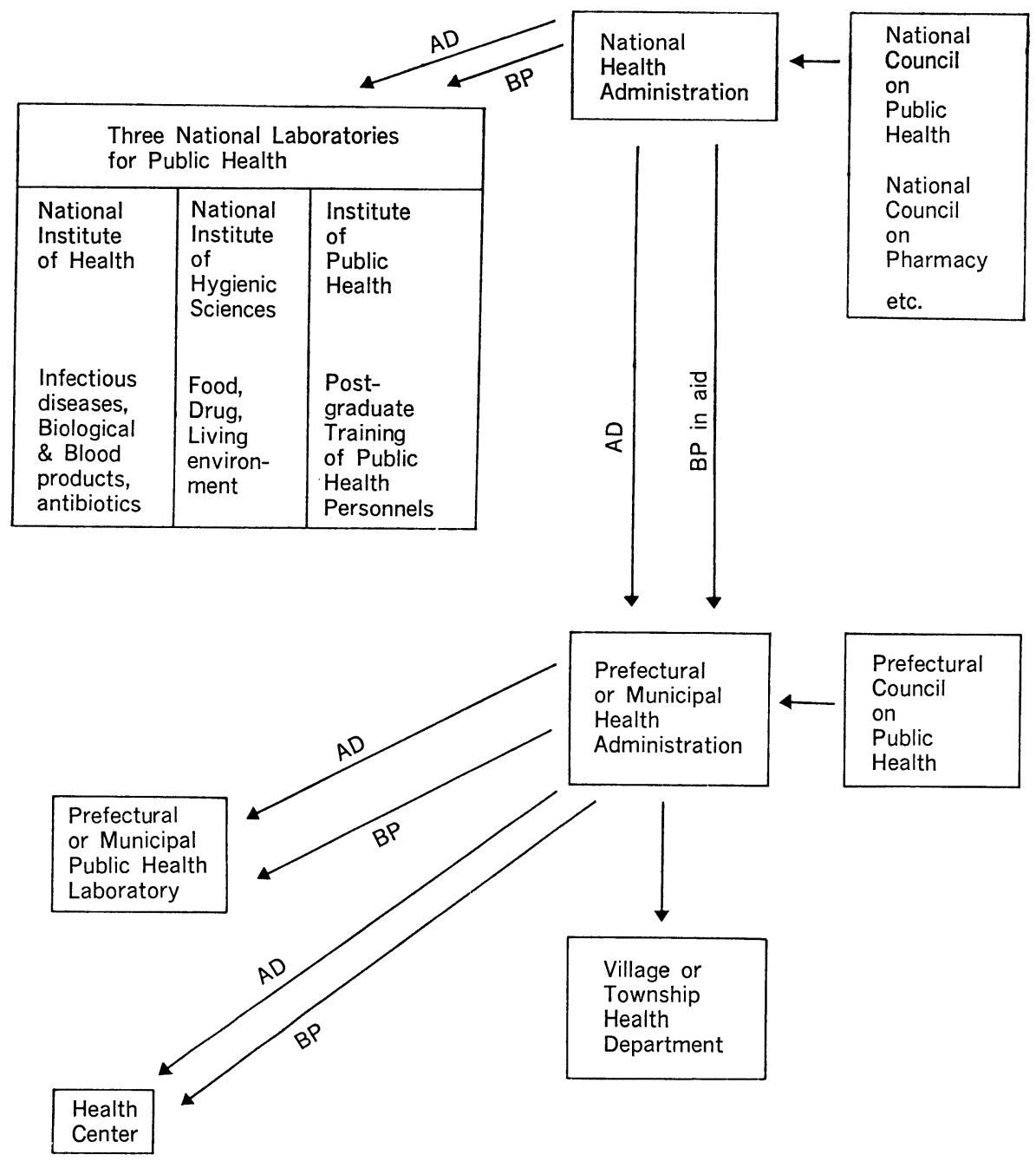

Fig. 1. The national network of public health laboratory services in Japan.

Note: AD-Administrative direction, $\mathrm{BP}-$ Budgetary provision.

(Kohno, 1968; Sakazaki, 1978). This dual system has been so deeply rooted for long years that it would be almost impossible to switch the present system into the combined type without much confusion. As far as clinical pathology is concerned, however, the doubling of work due to this dual system is not a big problem, since most DPHLs do not have the specialized division for that.

PHLS is in principle a network consisting of central reference laboratories at the national level, district (prefectural and municipal) public health laboratories at the intermediate level and health centers at the peripheral level (Fig. 1). The co-operative functioning in the formal style is possible only through the 
Health or Welfare Department of Prefectural Government
The Ministry of Health and Welfare of the National Government

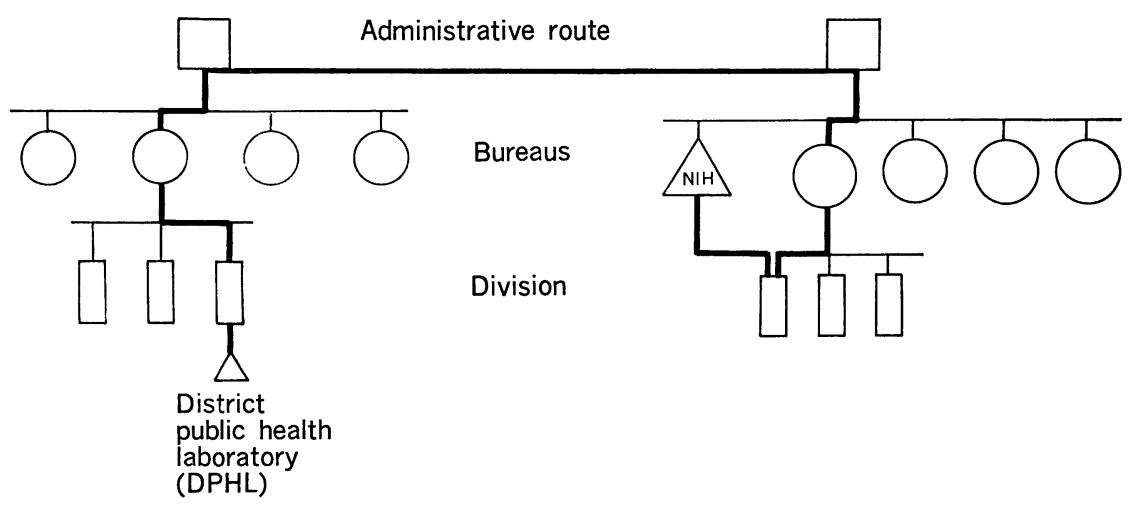

Fig. 2. Administrative channel between district public health laboratory and National Institute of Health (NIH).

administrative channel (Fig. 2). This is partly because the laboratories have no administrative power and partly because Japan has a federal type of government established on local autonomy. Therefore, there is a long administrative distance between national and district laboratories. Though this situation may sometimes be an obstacle to efficient and rapidly working mechanisms of PHLS, it is also true that the system has contributed much to the public health administration in our country.

DPHLs at the intermediate level are quite free to take the initiative or to fully respond to the needs and requirements of the district health agency and residents which they normally serve. On some occasions, however, the national health agency can execute the necessary administrative direction and budgetary provision in aid to DPHLs and health centers through the district and local health agencies (Fig. 1). The national health agency is of course responsible for maintenance of national laboratories through administrative arrangement and budgetary provision. As national institutions for public health, we have NIH for infectious disease control, National Institute of Hygienic Sciences (NIHS) for food and drug control and environmental health, and Institute of Public Health (IPH) for post-graduate training of public health personnels. These three national institutes are not only responsible for answering public health problems of national importance but also expected as supporting laboratories for DPHLs. In the case of NIH, it must be the central reference laboratory to provide stock cultures, strains, and immunologic reagents, to keep the uniformity of the testing work in DPHLs in the whole country. The functional association between NIH and DPHLs to perform their common duty of infectious disease control is illustrated in Fig. 3. In practice, there are some obstacles to keeping this association in a satisfactory manner, e.g., the complexity in the administrative procedure, poor manpower and shortage of money in both 


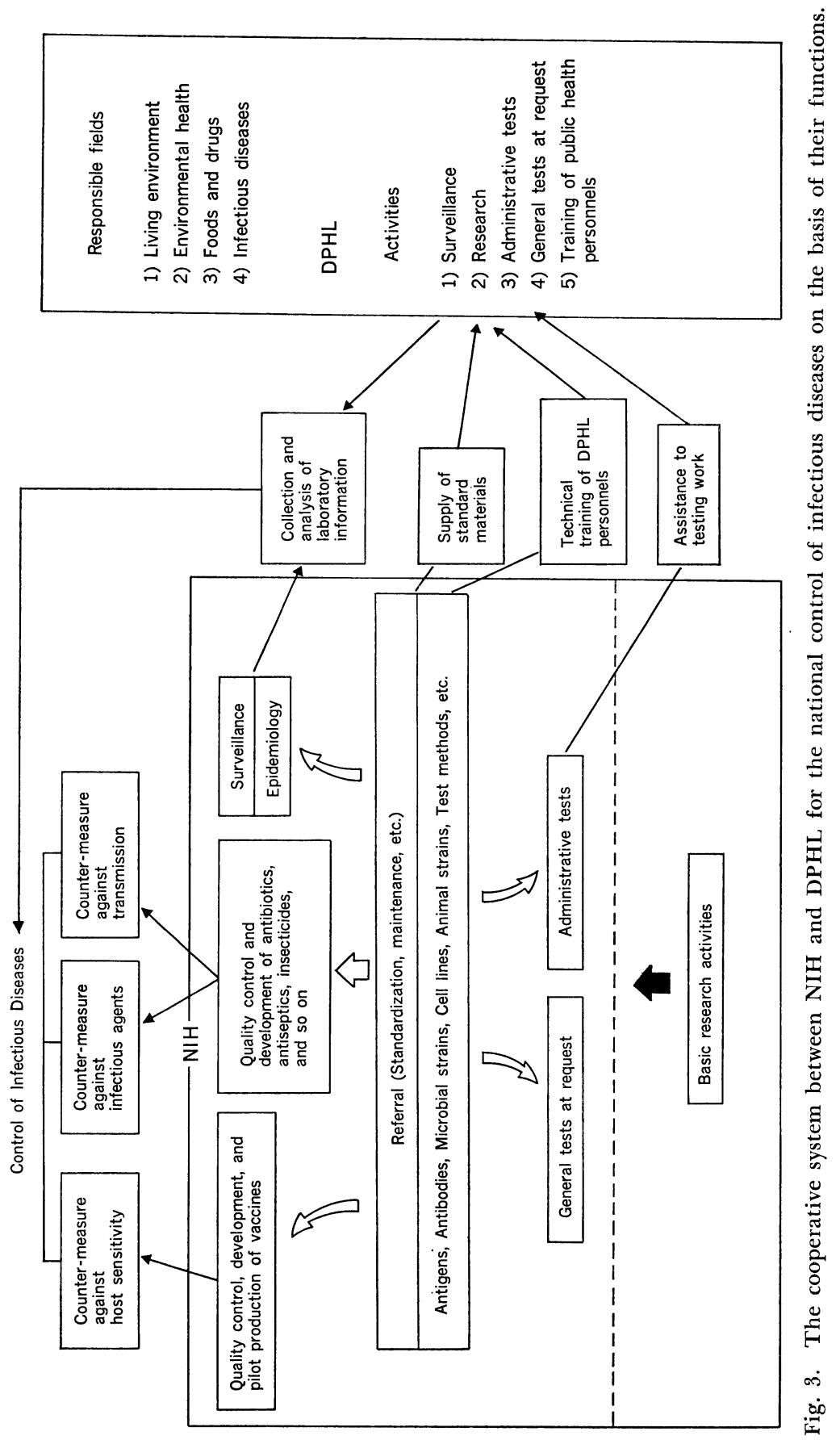




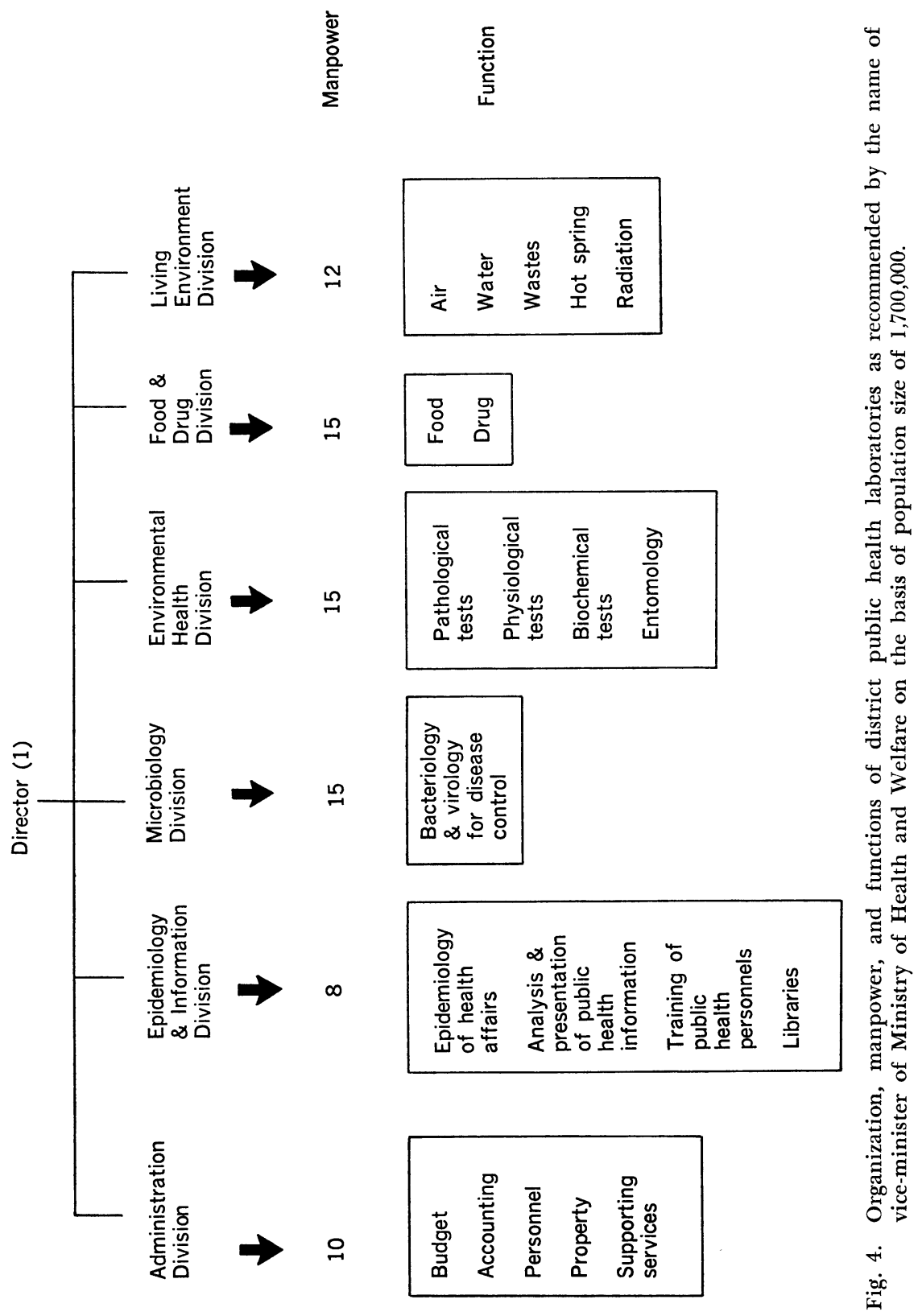


TABLE I

Manpower in prefectural and municipal public health laboratories

\begin{tabular}{|c|c|c|c|c|c|c|c|c|c|c|c|}
\hline \multirow[b]{2}{*}{ Year } & \multirow[b]{2}{*}{$\begin{array}{c}\text { Prefectural } \\
\text { or } \\
\text { municipal }\end{array}$} & \multirow[b]{2}{*}{$\begin{array}{c}\text { Total } \\
\text { number } \\
\text { of } \\
\text { PHL }\end{array}$} & \multirow[b]{2}{*}{$\begin{array}{l}\text { Average } \\
\text { number of } \\
\text { employees }\end{array}$} & \multicolumn{2}{|c|}{$\begin{array}{c}\text { Manpower } \\
\text { distribution } \\
(\%)\end{array}$} & \multicolumn{6}{|c|}{ Educational background of } \\
\hline & & & & $\begin{array}{l}\text { Admin- } \\
\text { istrative } \\
\& \\
\text { services }\end{array}$ & $\begin{array}{c}\text { Techni- } \\
\text { cal }\end{array}$ & 胥 & 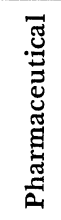 & 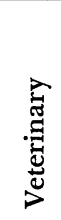 & 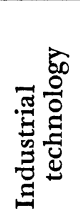 & 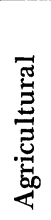 & 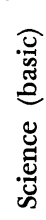 \\
\hline \multirow{2}{*}{1962} & Prefectural & 45 & 35.7 & 25.9 & 74.1 & 87 & 344 & 189 & 28 & 73 & 67 \\
\hline & Municipal & 14 & 33.9 & 25.3 & 74.7 & 19 & 86 & 31 & 24 & 41 & 32 \\
\hline \multirow{2}{*}{1966} & Prefectural & 46 & 42.6 & 21.8 & 78.2 & 91 & 476 & 218 & $\longrightarrow$ & 410 & \\
\hline & Municipal & 19 & 33.1 & 19.3 & 80.7 & 22 & 113 & 38 & & & \\
\hline \multirow{2}{*}{1979} & Prefectural & 46 & 52.4 & 15.2 & 84.8 & & & & & & \\
\hline & Municipal & 20 & 42. 1 & 13.2 & 86.8 & & & & & & \\
\hline
\end{tabular}

Survey by National Association of District Public Health Laboratories (NA-DPHLs)

NIH and DPHLs, and sometimes lack of concern about the co-operation among the staffs. In order to encourage the vertical scientific communication between $\mathrm{NIH}$ and DPHLs in a nonadministrative route, an association was organized in 1979 including DPHLs, NIH, NIHS and IPH. This association (Japanese Association of Public Health Microbiology) had the first annual meeting in June, 1980 in Tokyo to discuss their common problems in routine laboratory work and to exchange microbiological and epidemiological information relating to the topics of infectious diseases and food poisoning.

The national government and most prefectural governments have a council (board) which serves as an advisory body to the minister of health or his equivalent in determining public health policy. The council is usually divided into various special committees. The directors and staff of national and prefectural public health institutions are often the members of some of those committees. On the other hand, few prefectures have the advisory board for their own DPHL which may be composed of public health administrators, directors of national laboratories, scientists, epidemiologists and physicians. Actural overall direction of the laboratory services in DPHL is executed by an office of the prefectural health agency in consultation with the director and staff of DPHL. Each laboratory section of DPHL is in close contact with the individual division of the health bureau for planning and execution of their common duties.

Personnel recruitment between NIH and DPHLs has been done quite occasionally in such a pattern that a member of the staff of NIH is appointed to be the director or the section chief of DPHLs. Personnel recruitment among 


\begin{tabular}{|c|c|c|c|c|}
\hline \multicolumn{5}{|c|}{ technical manpower } \\
\hline 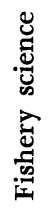 & 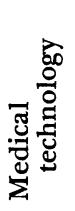 & 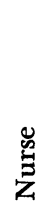 & 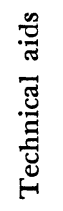 & $\begin{array}{l}\text { : } \\
\text { : } \\
0\end{array}$ \\
\hline 8 & 228 & 8 & 44 & 141 \\
\hline 6 & 52 & 2 & 14 & 47 \\
\hline - & 238 & 4 & 57 & 72 \\
\hline- & 94 & 7 & 25 & 25 \\
\hline
\end{tabular}

DPHL, health centers and health offices was also possible to make laboratory personnels acquainted with public health administration, and vice versa.

\section{Prefectural and Municipal Public Health Laboratories}

We have now 66 DPHLs in the whole country, 46 of which are PPHLs and the rest are municipal PHLs (MPHLs). DPHLs function as technical advisers for the district public health administration in the fields of infectious disease control, food and drug control, environmental health, and living environment (Fig. 3). The present status of DPHLs was reported recently by National Association of District Public Health Laboratories (1979).

According to the Vice-Minister's Notification issued on Nov. 10, 1976, the standard organization and manpower of DPHL are recommended as illustrated in Fig. 4 on the basis of population size of $1,700,000$. However, the financial situation of each district does not always allow to satisfy this standard, and Table I summarizes the present status of manpower in 66 DPHLs.

During the past 13 years, the average manpower increased from 35.7 to 52.4 in PPHLs and from 33.9 to 42.1 in MPHLs. In addition, the staff distribution in each DPHL has shifted to a higher rate of technical manpower. The educational backgrounds of technical staffs are so varied as shown in Table $I$. It indicates the increasing proportion of staff members whose specialities are pharmaceutical science or industrial technology. This is to respond to the increasing workload in food and drug control, environmental health, and living environment. The manpower for microbiology is shown in Table II. This 
TABLE II

Manpower for microbiology in DPHL, 1979

\begin{tabular}{|c|c|c|c|c|c|}
\hline $\begin{array}{c}\text { Total } \\
\text { number } \\
\text { of } \\
\text { DPHL }\end{array}$ & $\begin{array}{c}\text { Total } \\
\text { number } \\
\text { of } \\
\text { employees }\end{array}$ & $\begin{array}{c}\text { Total } \\
\text { manpower } \\
\text { for } \\
\text { micro- } \\
\text { biology }\end{array}$ & $\begin{array}{l}\text { Specialized } \\
\text { for }\end{array}$ & $\begin{array}{l}\text { Number of } \\
\text { staff in } \\
\text { each DPHL }\end{array}$ & $\begin{array}{c}\text { Number of DPHL } \\
\text { with the } \\
\text { left-indicated } \\
\text { manpower }\end{array}$ \\
\hline \multirow{8}{*}{66} & \multirow{8}{*}{3,313} & \multirow{8}{*}{$656(20 \%)$} & \multirow{4}{*}{ Bacteriology } & $0 \ldots \ldots \ldots \ldots$ & .............. 1 \\
\hline & & & & $1-2 \ldots \ldots \ldots \ldots$ & …................. \\
\hline & & & & 3-4.............. & 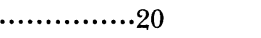 \\
\hline & & & & More than 5 & $\ldots \ldots \ldots \ldots \ldots+22$ \\
\hline & & & \multirow{4}{*}{ Virology } & $0 \ldots \ldots \ldots \ldots$ & $\ldots \ldots \ldots \ldots+10$ \\
\hline & & & & $1-2 \ldots \ldots \ldots \ldots$ & $\ldots \ldots+\cdots+18$ \\
\hline & & & & $3-4 \ldots \ldots \ldots \ldots$ & $\ldots \ldots \ldots \ldots \ldots .28$ \\
\hline & & & & More than 5 & $\ldots \ldots \ldots \ldots \ldots$ \\
\hline
\end{tabular}

Survey by NA-DPHLs

occupies about $20 \%$ (656) of the total manpower $(3,313)$ in 66 DPHLs. Most DPHLs have both bacteriology and virology sections to which technical staff are distributed as shown here to account for the respective services. This size of manpower for microbiology is not large enough and will not become larger because of the ever decreasing tendency of infectious diseases in this country. The main part of their responsibilities is now microbiological tests in outbreaks of food-poisoning and in the surveillance of some virus epidemics. The brief summary of these services is shown in Tables III to VI.

The recent investigation revealed that almost all DPHLs keep diagnostic antisera of commercial products for typhoid and paratyphoid bacilli, other Salmonella species, $S$. dysenteriae, $V$. parahemolyticus, $V$. cholerae, pathogenic $E$. coli, and $C$. perfringens, but only $60 \%$ of them maintain the standard strains of those bacterial species. Table III shows the general situation of bacteriological services, and it is seen here that DPHLs in our country have a fairly high level of testing work concerning enteric infection, food-poisoning, and syphilis serology.

As for virology, most DPHLs maintain Vero cells (83\%), HeLa cells $(70 \%)$, and MDCK cells $(70 \%$ ) for tissue culture (Table VI), and mice, suckling mice, guinea pigs, rabbits, fowls, and geese for experimental animals (80\%).

The standard strains of adenovirus, influenzavirus, poliovirus, Coxsackie A and $\mathrm{B}$, and echovirus are kept in about $60 \%$ of DPHLs and the antisera for adenovirus, influenzavirus, parainfluenzavirus, rubella virus, Japanese encephalitis virus, poliovirus, Coxsackie A \& B, echovirus, and enterovirus 67-71 are kept by a fairly large number of DPHLs.

Virus isolation and identification of adeno, influenza, Japanese encephalitis, polio, Coxsackie $\mathrm{A}$ and $\mathrm{B}$, and echo are the most frequent services, and $60 \%$ of DPHLs have such experiences. Serological test service is performed for more kinds of virus infection (Table V). 


\section{TABLE III}

Bacteriological services in 66 DPHLs in Japan, 1979

\begin{tabular}{|c|c|c|c|c|c|}
\hline \multirow[b]{2}{*}{ Bacteria } & \multicolumn{5}{|c|}{ Number of DPHLs with the below-indicated services } \\
\hline & None & Isolation & $\begin{array}{l}\text { Identification or } \\
\text { biochemical test }\end{array}$ & Typing & Toxin \\
\hline $\begin{array}{l}\text { Typhoid \& } \\
\text { Paratyphoid bacilli }\end{array}$ & 1 & 62 & 65 & $\begin{array}{c}65 \\
\text { (serovars) }\end{array}$ & \\
\hline Shigella & 0 & 64 & 66 & $\begin{array}{c}66 \\
\text { (serovars) }\end{array}$ & $\begin{array}{c}41 \\
\text { (colicin) }\end{array}$ \\
\hline Salmonella & 1 & 65 & 65 & $\begin{array}{c}62 \\
\text { (antigenicity) } \\
53 \\
\text { (serovars) }\end{array}$ & \\
\hline $\begin{array}{l}\text { Pathogenic } \\
\text { E. coli }\end{array}$ & 2 & 63 & 64 & $\begin{array}{c}58 \\
\text { (antigenicity) } \\
56 \\
\text { (serovars) }\end{array}$ & \\
\hline$V \cdot$ parahaemolyticus & 2 & 63 & 64 & $\begin{array}{c}61 \\
\text { (Kanagawa } \\
\text { phenomenon) } \\
64 \\
\text { (serovars) }\end{array}$ & \\
\hline Y. enterocolitica & 11 & 53 & 55 & $\begin{array}{c}40 \\
\text { (serovars) }\end{array}$ & \\
\hline C. perfringens & 6 & 60 & 60 & $\begin{array}{c}53 \\
\text { (Hobbs) }\end{array}$ & $\begin{array}{c}14 \\
\text { (enterotoxin) }\end{array}$ \\
\hline Staphylococcus & 1 & 65 & 65 & $\begin{array}{c}\text { (coagulase) } \\
22 \\
\text { (phage type) }\end{array}$ & $\begin{array}{c}21 \\
\text { (enterotoxin) }\end{array}$ \\
\hline C. botulinum & 39 & 27 & 26 & 18 toxin & type) \\
\hline B. cereus & 17 & 49 & 47 & & \\
\hline $\begin{array}{l}\text { Haemolytic } \\
\quad \text { streptococcus }\end{array}$ & 6 & 60 & 58 & $\begin{array}{c}52 \\
\text { (grouping) } \\
45 \\
\text { (A group-typing) }\end{array}$ & \\
\hline N. gonorrhoea & 9 & $\begin{array}{c}44 \\
57 \\
\text { (microscopy) }\end{array}$ & 38 & & \\
\hline C. diphtheriae & 20 & $\begin{array}{c}43 \\
46 \\
\text { (microscopy) }\end{array}$ & 40 & 20 (toxig & enicity) \\
\hline V. cholerae & 7 & 57 & 58 & $\begin{array}{c}56 \\
\text { (0-antigenicity) } \\
43 \\
\text { (biotype) }\end{array}$ & \\
\hline B. pertussis & 25 & 39 & 34 & & \\
\hline M. tuberculosis & 3 & 63 & 62 & $\begin{array}{c}62 \\
\text { (drug-resistance) }\end{array}$ & \\
\hline & & $\begin{array}{c}62 \\
\text { (microscopy) }\end{array}$ & & & \\
\hline Leptospira & 38 & $\begin{array}{c}22 \\
28 \\
\text { (microscopy) }\end{array}$ & 19 & & \\
\hline Fungi & 20 & 44 & $\begin{array}{c}42 \\
\text { (morphology) }\end{array}$ & $\begin{array}{c}24 \\
\text { (biochemical) }\end{array}$ & $\begin{array}{c}7 \\
\text { (mycotoxin) }\end{array}$ \\
\hline
\end{tabular}


TABLE IV

Serological services in 66 DPHLs in Japan, 1979

\begin{tabular}{llc}
\hline Infection with & \multicolumn{1}{c}{ Serological test } & $\begin{array}{c}\text { Number of DPHLs with } \\
\text { the } \begin{array}{c}\text { left-indicated } \\
\text { serological } \\
\text { services }\end{array}\end{array}$ \\
\hline Treponema & Microflocculation & 64 \\
& Agglutination & 61 \\
& Ogata test & 63 \\
TPHA & FTA-ABS & 63 \\
typhi \& paratyphi & Widal's reaction & 54 \\
\hline Hemolytic & ASO & 64 \\
streptococci & Passive hemagglutination & 46 \\
Mycoplasma & GF & 20 \\
\hline \multirow{2}{*}{ Leptospira } & Schüffner-Mochter & 16 \\
\hline Toxoplasma & Agglutination (latex) & 22 \\
& HA (latex) & 16 \\
\hline
\end{tabular}

Survey by NA-DPHLs
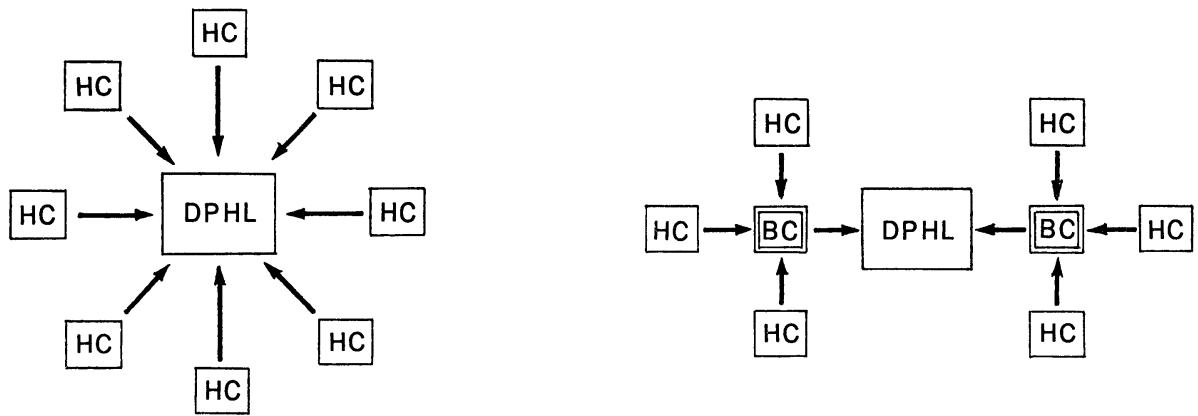

Fig. 5. Two different systems of the liaison between DPHL and health center in public health laboratory service (Kodama, 1968).

DPHL: District public health laboratory, HC: Health center, BC: Block center

The system of co-operation between DPHLs and health centers in microbiological services may be different from one district to another (Fig. 5). Generally speaking, there is now a tendency to centralize bacterial testing work in DPHLs. As far as virology is concerned, $\mathrm{HC}$ is playing a role of only specimen collection and transport to DPHLs (Table VII). 
TABLE V

Virological services in 61 DPHLs in Japan, 1979

\begin{tabular}{|c|c|c|c|c|c|c|c|c|c|c|c|c|c|c|}
\hline \multirow[b]{3}{*}{$\begin{array}{l}\text { Virus or } \\
\text { virus infection }\end{array}$} & \multicolumn{14}{|c|}{ Number of DPHL with the below-indicated virology services } \\
\hline & \multicolumn{4}{|c|}{ Virus isolation } & \multicolumn{5}{|c|}{ Identification } & \multicolumn{5}{|c|}{ Serology (antibody) } \\
\hline & 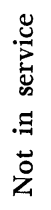 & 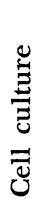 & 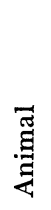 & 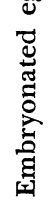 & 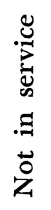 & 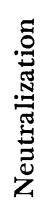 & 踏 & 正 & 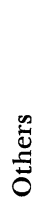 & $\begin{array}{l}\stackrel{\circlearrowright}{8} \\
\stackrel{0}{0} \\
. \Xi \\
\ddot{0} \\
\ddot{Z}\end{array}$ & 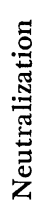 & 岂 & 证 & $\frac{\infty}{\stackrel{d}{ \pm ் ~}}$ \\
\hline Herpes simplex & 33 & 27 & 2 & 9 & 34 & 19 & 13 & 0 & 7 & 28 & 14 & 24 & 3 & 8 \\
\hline $\begin{array}{l}\text { Varicella \& } \\
\text { Herpes zoster }\end{array}$ & 51 & 9 & 1 & 2 & 50 & 4 & 5 & 0 & 4 & 39 & 4 & 20 & 0 & 3 \\
\hline Cytomegalovirus & 55 & 6 & 0 & 0 & 57 & 0 & 2 & 0 & 2 & 49 & 1 & 11 & 0 & 1 \\
\hline Adenovirus & 14 & 47 & 0 & 0 & 14 & 38 & 28 & 13 & 2 & 12 & 28 & 40 & 16 & 3 \\
\hline Influenza & 2 & 42 & 2 & 51 & 1 & 13 & 19 & 59 & 14 & 1 & 12 & 23 & 60 & 18 \\
\hline Parainfluenza & 31 & 26 & 0 & 5 & 27 & 3 & 3 & 33 & 7 & 10 & 4 & 3 & 51 & 3 \\
\hline Measles & 49 & 12 & 0 & 0 & 43 & 10 & 5 & 7 & 1 & 19 & 7 & 18 & 37 & 1 \\
\hline Mumps & 42 & 15 & 0 & 9 & 37 & 7 & 4 & 23 & 0 & 22 & 4 & 17 & 31 & 0 \\
\hline RS virus & 50 & 11 & 0 & 0 & 49 & 0 & 4 & 0 & 2 & 44 & 6 & 13 & 0 & 0 \\
\hline Coronavirus & 60 & 1 & 0 & 0 & 60 & 0 & 1 & 1 & 0 & 60 & 0 & 0 & 1 & 0 \\
\hline Rubella & 31 & 30 & 0 & 0 & 23 & 22 & 8 & 31 & 4 & 0 & 9 & 18 & 61 & 6 \\
\hline $\begin{array}{l}\text { Japanese } \\
\text { encephalitis }\end{array}$ & 21 & 17 & 36 & 0 & 17 & 7 & 19 & 39 & 15 & 4 & 24 & 27 & 57 & 11 \\
\hline Reovirus & 52 & 9 & 0 & 0 & 51 & 4 & 2 & 3 & 0 & 50 & 6 & 2 & 6 & 2 \\
\hline Polio & 16 & 45 & 0 & 0 & 18 & 39 & 7 & 0 & 1 & 14 & 46 & 16 & 0 & 2 \\
\hline Coxsackie A & 13 & 40 & 40 & 0 & 18 & 42 & 12 & 0 & 3 & 18 & 43 & 18 & 1 & 2 \\
\hline Coxsackie B & 14 & 46 & 18 & 0 & 18 & 42 & 6 & 3 & 2 & 15 & 45 & 19 & 5 & 4 \\
\hline Echovirus & 16 & 44 & 3 & 0 & 18 & 43 & 6 & 3 & 2 & 16 & 42 & 12 & 8 & 2 \\
\hline Rhinovirus & 56 & 5 & 0 & 0 & 54 & 5 & 1 & 0 & 2 & 54 & 6 & 2 & 2 & 8 \\
\hline Enterovirus $68-71$ & 28 & 33 & 7 & 0 & 30 & 36 & 4 & 0 & 2 & 30 & 6 & 1 & 3 & 34 \\
\hline Vaccinia & 47 & 9 & 0 & 10 & 49 & 5 & 5 & 6 & 3 & 47 & 6 & 7 & 10 & 1 \\
\hline
\end{tabular}

Survey by NA-DPHLs

\section{Health Centers}

General description: In 1935, the first health center as a model was established in Tokyo. Then in 1937, the original Health Center Law was enacted, on which the 10-year program of health center construction started. In 1944, the total number of health centers reached 77 in the whole country. In these days, health centers were engaged in only health consultations of tuberculosis, maternal and child health, and health promotion of pre-servicemen.

After the end of World War II, the Health Center Law was completely 
TABLE VI

The status of maintenance of cell lines for virology in DPHL, 1979

\begin{tabular}{lc}
\hline \multicolumn{1}{c}{ Cell lines } & $\begin{array}{c}\text { Number of DPHL maintaning routinely } \\
\text { the left-indicated cell line }\end{array}$ \\
\hline No cell line maintained & 10 \\
MK & 16 \\
Vero & 51 \\
HeLa & 44 \\
MDCK & 43 \\
Hep-2 & 35 \\
HEL & 28 \\
FL & 22 \\
BHK & 30 \\
Others* & 37 \\
\hline
\end{tabular}

* BK-13, HEK, S 3, KB, RK-13, GMK, CMK, etc. Survey by NA-DPHLs in 1979

\section{TABLE VII}

The status of co-operation between DPHL and health centers $(H C)$ in microbiology

\begin{tabular}{|c|c|c|c|c|c|c|c|c|c|c|c|c|c|c|}
\hline & \multicolumn{6}{|c|}{ Bacteriology } & \multicolumn{8}{|c|}{ Viology } \\
\hline & \multirow{2}{*}{\multicolumn{2}{|c|}{$\begin{array}{c}\text { Share } \\
\text { duties } \\
\text { between } \\
\text { DPHL } \\
\text { and HC }\end{array}$}} & \multirow{2}{*}{\multicolumn{2}{|c|}{$\begin{array}{c}\begin{array}{c}\text { Forwarding } \\
\text { bacterial } \\
\text { isolates from } \\
\text { HC to DPHL }\end{array} \\
\end{array}$}} & \multirow{2}{*}{\multicolumn{2}{|c|}{$\begin{array}{c}\text { Training HC } \\
\text { personnels } \\
\text { by DPHL } \\
\end{array}$}} & \multicolumn{4}{|c|}{$\begin{array}{l}\text { Specimen- } \\
\text { collection in } \\
\text { epidemics by }\end{array}$} & \multicolumn{4}{|c|}{$\begin{array}{l}\text { Transport of } \\
\text { specimens by }\end{array}$} \\
\hline & & & & & & & \multicolumn{2}{|c|}{ DPHL } & \multirow{2}{*}{\multicolumn{2}{|c|}{ HC HA* }} & \multicolumn{2}{|c|}{ DPHL } & \multirow{2}{*}{\multicolumn{2}{|c|}{$\mathrm{HC} \mathrm{HA}$}} \\
\hline & Yes & No & $\underset{\text { strains }}{\text { All }}$ & Partly & Reg. & Irreg. & Reg. & Irreg. & & & Reg. & Irreg. & & \\
\hline $\begin{array}{c}\text { Number } \\
\text { of } \\
\text { munici- } \\
\text { palities } \\
\text { (Total 66) }\end{array}$ & 36 & 14 & 7 & 43 & 30 & 25 & 4 & 17 & 23 & 4 & 4 & 19 & 23 & 3 \\
\hline
\end{tabular}

* HA: Health administrative bureau Survey by NA-DPHLs

revised in 1947 to reorganize the public health program. The law defined that the prefectural governments are responsible for establishment of health centers with the subsidy from the national government. Their roles were defined to function primarily as the community health service agency and secondarily as the health administration-supervising agency based on the authority delegated by the prefectural governor or city mayor. The director of the health center should be a medical doctor.

As of the end of April 1976, there were a total of 843 health centers and almost 24,000 employees including about 1,600 of physicians and dentists, about 5,000 of pharmacists, veterinarians, nutritionists, X-ray technicians, laboratory technicians and dental hygienists, about 7,000 of public health nurses, midwives 
and nurses, and about 10,000 of health statisticians, health educators, social caseworkers, mental health counselors, food inspectors and sanitary inspectors.

The basic functions defined by the Health Center Law are as follows: health education, vital and health statistics, improvement of nutrition and food sanitation, environmental health, public health nursing, medical social service, laboratory service, mental health, prevention and control of tuberculosis, venereal diseases and other communicable diseases, maternal and child health, dental hygiene, and other local health programs as required, such as specific endemic control, etc. As a routine program, the health consultation clinic, well-baby conference, mass chest examination, home visit, community health education, inspection and field supervision on sanitary operation are carried out. The health education is integrated into every phase of the routine program. The control of adult diseases such as stomach cancer and cerebro-vascular disease, TB control, environmental pollution control, nutrition and child health promotion are the highlight programs.

The health center is financed by the local and national governments. The item of national subsidy is divided into two categories, one is the health center subsidy based on Health Center Law and the other is the program subsidy based on other respective legislations concerned. The national government is responsible for sharing the cost of health center expenditure, both recurrent and non-recurrent ones. When the health center is newly established, the national government shares one half of the expenditure for construction and necessary equipments. It also subsidizes one third of the running expenses and the local government pays the rest (Koseisho, 1974).

Laboratory services in health center: Laboratory services in health centers are classified into five categories; microbiology, clinical pathology, pharmacology, environmental hygiene, and food sanitation. The main activities in microbiology have long been concerned with dysentery and tuberculosis, though there is little need for those at the present time. Simple tests in syphilis serology and microscopy of gonococci have also been the routine work in health centers. Laboratory work in health centers is performed independently or by receiving technical assistance from DPHL. Test duties are shared between them, but health centers do sometimes only specimen collection and forwarding the collected specimens to DPHL (Table VII).

\section{National Laboratories}

The National Institute of Health $(\mathrm{NIH})$ : This institute was founded in 1947 as the central research laboratory associated with MHW to answer public health problems of national importance, mainly in the field of infectious diseases. Its establishment was urgent at that time in view of the unusual epidemiological situation just after the end of World War II. The quality control of vaccines, antisera, immunologic reagents, antibiotics, and antiseptics was the top duty along with the surveillance of infectious diseases and the basic research of micro- 
TABLE VIII

Number of biologicals (lots) accepted for the national assay in NIH

\begin{tabular}{lrrr}
\hline \multicolumn{1}{c}{ Biologicals } & \multicolumn{3}{c}{ Year } \\
\cline { 2 - 4 } & 1960 & 1969 & 1978 \\
\hline Bacterial vaccines and toxoids & 813 & 420 & 188 \\
Virus vaccines & 203 & 328 & 266 \\
Antibiotics & 6511 & 4560 & 14237 \\
Blood products & 167 & 525 & 863 \\
\hline
\end{tabular}

Annual Report of NIH, 1960, 1969, 1978

TABLE IX

Number of DPHLs which were in contact with NIH asking for services in administrative tests

\begin{tabular}{cc}
\hline Year & Number of DPHLs \\
\hline 1969 & 22 \\
1970 & 22 \\
1971 & 18 \\
1972 & 12 \\
1973 & 23 \\
1974 & 12 \\
1975 & 18 \\
1976 & 20 \\
1977 & 26 \\
1978 & 37 \\
\hline
\end{tabular}

Annual Report of NIH, 1969-1978

\section{TABLE X}

Number of tests for administrative purpose conducted by main departments of NIH in the past 9 years from 1970 to 1978

\begin{tabular}{lc}
\hline \multicolumn{1}{c}{ Department } & Number of tests \\
\hline Central Virus Diagnostic Laboratory & 7318 \\
Dept. of Enteroviruses & 995 \\
Dept. of Virology and Rickettsiology & 337 \\
Dept. of Bacteriology I & 80 \\
Dept. of General Biologics Control & 28 \\
Dept. of Bacteriology II & 10 \\
Dept. of Biomedical Research on Foods & 1397 \\
\hline
\end{tabular}

Annual Report of NIH, 1970-1978

biology and immunology. As stated before, the reference activity has also been one of the main functions as an integral part of the national network for public health laboratory services, maintaining and providing the standards of microbial strains, cell lines, experimental animals, antisera, antibiotics, etc. Meanwhile, 
TABLE XI

Administrative tests in NIH in the past 11 years

\begin{tabular}{|c|c|c|c|c|c|c|c|c|c|c|c|}
\hline \multirow{2}{*}{ Test items } & \multicolumn{11}{|c|}{ Number of tests conducted in the year } \\
\hline & 1969 & 1970 & 1971 & 1972 & 1973 & 1974 & 1975 & 1976 & 1977 & 1978 & 1979 \\
\hline Virological tests & 5 & 0 & 1 & 1 & 8 & 1 & 1 & 0 & 0 & 11 & 4 \\
\hline $\begin{array}{l}\text { Antigenic analysis } \\
\text { of virus isolates }\end{array}$ & 0 & 0 & 53 & 0 & 22 & 13 & 29 & 60 & 6 & 0 & 0 \\
\hline \multicolumn{12}{|l|}{$\begin{array}{l}\text { Isolation and identifica- } \\
\text { tion of viruses }\end{array}$} \\
\hline 1) Electronmicroscopy & 0 & 0 & 0 & 0 & 0 & 0 & 0 & 37 & 21 & 84 & 76 \\
\hline $\begin{array}{l}\text { 2) Tissue culture or } \\
\text { embryonated egg }\end{array}$ & 137 & 14 & 52 & 236 & 240 & 450 & 308 & 158 & 589 & 648 & 466 \\
\hline 3) Marker test & 23 & 17 & 6 & 2 & 3 & 10 & 3 & $\mathbf{0}$ & 9 & 9 & 3 \\
\hline 4) Suckling mouse & 0 & 75 & 115 & 0 & 0 & 51 & 61 & 8 & 0 & 3 & 8 \\
\hline \multicolumn{12}{|l|}{ Serological test } \\
\hline $\begin{array}{l}\text { 1) Complement } \\
\text { binding antibody }\end{array}$ & 52 & 12 & 108 & 81 & 142 & 552 & 1738 & 722 & 154 & 297 & 117 \\
\hline $\begin{array}{l}\text { 2) Neutralizing anti- } \\
\text { body } \\
\text { (Tissue culture) }\end{array}$ & 449 & 366 & 96 & 513 & 408 & 181 & 13 & 26 & 53 & 97 & 130 \\
\hline $\begin{array}{l}\text { Identification of } \\
\text { bacterial isolates }\end{array}$ & 101 & 4 & 9 & 0 & 5 & 0 & 3 & 11 & 17 & 34 & 52 \\
\hline Food toxicity & 0 & 3 & 561 & 739 & 0 & 1 & 0 & 29 & 2 & 8 & 41 \\
\hline Antibiotics & 0 & 1 & 0 & 1 & 0 & 1 & 2039 & 0 & 0 & 0 & 470 \\
\hline Protozoa. Parasites & 3 & 0 & 1 & 0 & 10 & 3 & 0 & 0 & 0 & 0 & 0 \\
\hline
\end{tabular}

Annual Report of NIH, 1968-1979

TABLE XII

Bacterial typing services in NIH

\begin{tabular}{ll}
\hline \multicolumn{1}{c}{ Types } & \multicolumn{1}{c}{ Species } \\
\hline & Salmonella \\
& Pathogenic Escherichia coli \\
& Vibrio cholerae 0-1 and other 0-types (NAG) \\
& Listeria monocytogenes \\
& Bordetella pertussis \\
Serovars & Leptospira \\
& Serratia \\
\hline & Vibrio cholerae 0-1 \\
& Salmonella typhi and $S$. paratyphi \\
& Salmonella typhimurium \\
& Staphylococcus aureus \\
& Acid fast bacteria \\
\hline & Yersinia pestis \\
Identification of & Legionella pneumophila \\
special pathogens & Passteurella multocida \\
& Pseudomonas pseudomallei \\
\hline
\end{tabular}


TABLE XIII

Number of bacterial strains subjected to identification in the First Department of Bacteriology of NIH (Annual Report of NIH, 1976-1980)

\begin{tabular}{cccc}
\hline \multirow{2}{*}{ Year } & \multicolumn{3}{c}{ Strains } \\
\cline { 2 - 4 } & From inland & From abroad & Total \\
\hline 1976 & 444 & 478 & 922 \\
1977 & 1121 & 217 & 1333 \\
1978 & 1197 & 368 & 1565 \\
1979 & 3110 & 396 & 3506 \\
1980 & 2650 & 433 & 3083 \\
\hline
\end{tabular}

These strains include those for administrative, surveillance and research purposes.

TABLE XIV

Number of bacterial strains whose species were identified in the

First Department of Bacteriology of NIH in 1979

\begin{tabular}{lcc}
\hline \multicolumn{1}{c}{ Species } & \multicolumn{2}{c}{ Number of strains } \\
\cline { 2 - 3 } & From inland & From abroad \\
\hline Salmonella & 1045 & 68 \\
Enteric bacteria other than Salmonella & 462 & \\
Vibrio cholerae 0-1 & 26 & 305 \\
Vibrio cholerae other than 0-1 & 1096 & 14 \\
Vibrio parahaemolyticus & & 9 \\
Plesiomonas shigelloides & 21 & \\
Gram-negative fermentative rods & 69 & 396 \\
Gram-negative nonfermentative rods & 391 & \\
Coagulase-negative staphylococci & 3110 & \\
\hline \multicolumn{2}{c}{ Total } &
\end{tabular}

Annual Report of NIH, 1979

the institute has been playing a role as an adviser or consultant for national health administration and of a trainer of public health personnels (Yanagisawa, 1977).

The organization of NIH is presently consisting of one administrative office, 18 research departments (Bacteriology I, Bacteriology II, Tuberculosis, Virology and Rickettsioloy, Enteroviruses, Measles Virus, Central Virus Diagnostic Laboratory, Blood Products, General Biologics Control, Antibiotics, Parasitology, Medical Entomology, Veterinary Sciences, Biomedical Research on Foods, Dental Research, Chemistry, Pathology, and Technology), one center (Tsukuba Primate Center for Medical Science) and one library. The premises of the institute are separated into two locations, the main one in down-town Tokyo (Shinagawa-ku) and the other in the western outskirts (Murayama). The Tsukuba Primate Center for Medical Science was established in 1978, at Tsukuba Science City, Ibaragi Prefecture. 
TABLE XV

Salmonella surveillance on the strains sent to the First Department of Bacteriology of NIH in the past 10 years

\begin{tabular}{cccccc}
\hline Year & \multicolumn{5}{c}{ Number of strains tested } \\
\cline { 2 - 6 } & $\begin{array}{c}\text { Human } \\
\text { origin }\end{array}$ & $\begin{array}{c}\text { Food } \\
\text { origin }\end{array}$ & $\begin{array}{c}\text { Other sources } \\
\text { (surface water, } \\
\text { animals, etc) }\end{array}$ & Total & $\begin{array}{c}\text { Number of } \\
\text { classified } \\
\text { serotypes }\end{array}$ \\
\hline 1970 & 590 & 3600 & & 4190 & 105 \\
1971 & 135 & 570 & & 705 & 125 \\
1972 & 200 & 120 & 35 & 320 & 38 \\
1973 & 773 & & 118 & 373 & 105 \\
1974 & 125 & 158 & 124 & 352 & 46 \\
1975 & $?$ & $?$ & & 676 & 43 \\
1976 & 326 & & & 785 & 32 \\
1977 & 320 & 232 & & 1045 & 54 \\
1978 & 750 & 35 & & & 98 \\
1979 & 1045 & & & & \\
\hline
\end{tabular}

Annual Report of NIH, 1970-1979

\section{TABLE XVI}

Increasing variety of Salmonella serovars in Japan in the past 30 years (Japan Salmonella Center)

\begin{tabular}{cl}
\hline Year & Number of serovars \\
\hline Uutil 1950 & More than 95\% were \\
& S. enteritidsi. \\
Since around 1955 & The majority were \\
& S. typhimurium. \\
1965 & 18 \\
1970 & 41 \\
& 96 \\
\hline
\end{tabular}

A total of 481 employees were working in 1979, distributing 390 to laboratories and 90 to administrative and supporting services. The educational backgrounds of laboratory staffs are various; medical and dental sciences, veterinary science, pharmacology, biological sciences, medical technology, and some others.

NIH has contributed greatly to the control of infectious diseases mainly through the quality control and development of bacterial and viral vaccines and the surveillance activity in co-operation with DPHLs and other medical facilities. In addition, $\mathrm{NIH}$ has been active in basic research relating not only to infectious diseases but also to broader aspects of life science. Some of the staff in this field became the top-ranking researchers in the world and their achievements have been highly evaluated at the international level. However, the detailed introduction of them is not within the scope of the present report. As stated repeatedly, one of the basic characters of $\mathrm{NIH}$ is the central reference 
TABLE XVII

Dominant serovars of Salmonella isolates from human specimens in 1978 (Japan Salmonella Center)

\begin{tabular}{lr}
\hline \multicolumn{1}{c}{ Serovars } & $\%$ \\
\hline S. typhimurium & 15.5 \\
S. cerro & 6.9 \\
S. agona & 5.9 \\
S. infantis & 4.9 \\
S. anatum & 4.0 \\
S. enteritidis & 3.1 \\
S. give & 3.1 \\
S. tennessee & 3.1 \\
S. thompson & 3.0 \\
\hline
\end{tabular}

\section{TABLE XVIII}

Percentage of the typhoid and paratyphoid patients whose isolates were subjected to phage-typing in the total reported cases (the National Center for Enteric Phage Typing)

\begin{tabular}{|c|c|c|c|c|c|c|}
\hline \multirow{2}{*}{ Year } & \multicolumn{3}{|c|}{ Typhoid } & \multicolumn{3}{|c|}{ Paratyphoid } \\
\hline & $\begin{array}{l}\text { Reported } \\
\text { cases }\end{array}$ & $\begin{array}{c}\text { Phage-typed } \\
\text { isolates }\end{array}$ & $\%$ & $\begin{array}{l}\text { Reported } \\
\text { cases }\end{array}$ & $\begin{array}{c}\text { Phage-typed } \\
\text { isolates }\end{array}$ & $\%$ \\
\hline 1967 & 497 & 271 & 55 & 131 & 58 & 44 \\
\hline 1968 & 419 & 240 & 57 & 64 & 57 & 89 \\
\hline 1969 & 420 & 275 & 65 & 72 & 51 & 76 \\
\hline 1970 & 239 & 152 & 64 & 54 & 26 & 48 \\
\hline 1971 & 316 & 216 & 68 & 44 & 26 & 59 \\
\hline 1972 & 344 & 254 & 74 & 56 & 29 & 52 \\
\hline 1973 & 302 & 218 & 72 & 48 & 36 & 75 \\
\hline 1974 & 325 & 246 & 76 & 56 & 35 & 63 \\
\hline 1975 & 570 & 423 & 74 & 73 & 42 & 58 \\
\hline 1976 & 435 & 341 & 78 & 82 & 59 & 72 \\
\hline 1977 & 384 & 341 & 89 & 76 & 62 & 82 \\
\hline 1978 & 437 & 382 & 87 & 128 & 110 & 86 \\
\hline 1979 & 496 & 431 & 87 & 147 & 119 & 81 \\
\hline Total & 5184 & 3790 & 73 & 1031 & 710 & 69 \\
\hline
\end{tabular}

laboratory for microbiology in the national network of public health laboratory services for the control of infectious diseases. The co-operative relationship in this respect between NIH and DPHLs is shown shematically in Fig. 3. Because of the necessity of international association in such reference activity, NIH has been assigned to many WHO centers as listed below.

National Centers

National Salmonella Center (WHO)

National Shigella Center (WHO) 
TABLE XIX

Dominant phage types of typhoid bacilli isolated in Japan (the National Center for Enteric Phage Typing)

\begin{tabular}{|c|c|c|c|c|c|c|c|c|c|c|}
\hline \multirow{2}{*}{ Year } & \multicolumn{10}{|c|}{ Order of frequency (high to low) } \\
\hline & 1 & 2 & 3 & 4 & 5 & 6 & 7 & 8 & 9 & 10 \\
\hline $1956 \sim 1966$ & D 2 & M1 & E 1 & D 1 & A deg. & A & $\mathrm{UT}^{* *}$ & D 6 & B 2 & 39 \\
\hline 1967 & $\mathrm{D} 2$ & A deg. & E 1 & M1 & 53 & D 1 & $\mathbf{H}$ & 39 & D 6 & B 2 \\
\hline 1968 & D 2 & E 1 & M1 & A deg. & D 1 & B 2 & A & 46 & 53 & D 6 \\
\hline 1969 & D 2 & A dag. & M1 & E 1 & D 1 & UT & $\mathrm{H}$ & B 2 & 53 & D 6 \\
\hline 1970 & D 2 & E 1 & D 1 & A deg. & A deg. & UT & A & B 2 & 53 & E11 \\
\hline 1971 & D 2 & E 1 & M1 & D 1 & A deg. & $\mathbf{A}$ & 53 & B 1 & $\mathbf{H}$ & B 2 \\
\hline 1972 & D 2 & D 1 & E 1 & 53 & A deg. & UT & M1 & A & B 2 & $\mathbf{H}$ \\
\hline 1973 & D 2 & M1 & E 1 & D 1 & 53 & A deg. & A & D 6 & $\mathrm{H}$ & 46 \\
\hline 1974 & M1 & D 2 & 53 & M1 & D 1 & $\mathbf{U T}$ & A deg. & B 2 & A & $\mathbf{H}$ \\
\hline 1975 & $\mathrm{D} 2$ & M1 & E 1 & A deg. & 53 & A & D 1 & D 6 & $\mathrm{H}$ & B 2 \\
\hline 1976 & M1 & E 1 & D 2 & A deg. & 53 & $\mathbf{U T}$ & D 1 & A & $\mathbf{H}$ & B 2 \\
\hline 1977 & D 2 & M1 & E 1 & A deg. & 53 & UT & D 1 & A & B 2 & 46 \\
\hline 1978 & M1 & D 2 & A deg. & E 1 & UT & D 1 & 53 & A & 46 & B 2 \\
\hline
\end{tabular}

* A degraded

** Untyped

National Center for Enteric Phage-typing (International Association of Microbiological Societies)

National Influenza Center (WHO)

National Blood Group Reference Center (WHO)

Regional Centers

Collaborating Center for Virus Reference and Research (Enteroviruses) (WHO)

Collaborating Center for Poxvirus Research (WHO)

Collaborating Center for Respiro-viruses other than Influenza Virus (WHO)

Collaborating Center for Arbovirus Reference and Research (WHO)

Collaborating Center for Standardization of Laboratory Procedures for the Diagnosis of Mycobacterial Diseases and for Bacteriological Research (WHO)

Collaborating Center for Research and Reference Services for certain Immunological Biological Products (WHO)

Collaborating Center for Research and Reference Services of Antibiotics (WHO)

Collaborating Center for Defined Laboratory Animals (WHO)

Reference Laboratory

Serum Reference Bank (WHO)

Instead of describing the overall past records of the testing work for the quality control of biologics and reference activity, Tables VIII to XIX were 


\section{TABLE XX}

Number of public health personnels accepted for laboratory base training at two different levels

\begin{tabular}{ccc}
\hline \multirow{2}{*}{ Year } & \multicolumn{2}{c}{ Number of trainees } \\
\cline { 2 - 3 } & Class 1 & Class 2 \\
\hline 1965 & 27 & 39 \\
1966 & 43 & 48 \\
1967 & 26 & 32 \\
1968 & 34 & 28 \\
1969 & 31 & 37 \\
1970 & 52 & 95 \\
1971 & 56 & 68 \\
1972 & 71 & 96 \\
1973 & 51 & 68 \\
1974 & 69 & 86 \\
1975 & 51 & 54 \\
1976 & 50 & 55 \\
1977 & 67 & 54 \\
1978 & 72 & 68 \\
\hline
\end{tabular}

Annual Report of NIH, 1965-1978

TABLE XXI

Ten leading causes of death in Japan

\begin{tabular}{|c|c|c|c|c|c|c|}
\hline \multirow{2}{*}{ Causes of death } & \multicolumn{3}{|c|}{ Number of deaths } & \multicolumn{3}{|c|}{ Death rate per 100,000} \\
\hline & 1965 & 1974 & 1978 & 1965 & 1974 & 1978 \\
\hline Cerebrovascular diseases & 172,773 & 178,333 & 167,431 & 175.8 & 163.0 & 146.2 \\
\hline Malignant nepolasms & 106,536 & 133,702 & 150,265 & 108.4 & 122.0 & 131.2 \\
\hline Heart diseases & 75,672 & 98,169 & 106,749 & 77.0 & 89.7 & 93.2 \\
\hline Pneumonia \& bronchitis & 36,663 & 35,677 & 34,676 & 37.3 & 32.6 & 30.3 \\
\hline Accidents & 40,188 & 35,664 & 29,776 & 40.9 & 32.6 & 26.0 \\
\hline Senility & 49,092 & 32,476 & 27,972 & 50.0 & 29.7 & 24.4 \\
\hline Hypertensive diseases & 18,987 & 20,109 & 16,776 & 19.3 & 18.4 & 16.4 \\
\hline Suicide & 14,444 & 19,085 & 20,187 & 14.7 & 17.4 & 17.6 \\
\hline Tuberculosis & 22,366 & 11,410 & 8,258 & 22.8 & 10.4 & 7.2 \\
\hline Cirrhusis of liver & 9,791 & 14,645 & 16,073 & 10.0 & 13.4 & 14.0 \\
\hline
\end{tabular}

National Survey of Mortality and Morbidity

prepared as the selected but representative materials which make the general trend understandable at a glance.

The most typical examples of the reference activity in NIH are those in Central Virus Diagnostic Laboratory. This laboratory was established in 1963 at the strong social request for the national organization of a virus reference and diagnostic laboratory, especially as a supporting laboratory for DPHLs and hospital laboratories of the whole country. 
Not only the work of virus isolation and identification from suspected materials (Table XI), the preparation and supply of reagents for diagnosis of virus infection has also been an important part of the reference activity. Up to 1972, 22 kinds of antiserum and 24 kinds of antigen have been prepared to meet the needs arising from the epidemiological situation of virus infection. At the same time, the laboratory has been concerned with the quality control of commercial antisera and antigens, especially at the time of licence. Twentyeight kinds of each have been approved so far. With the increasing availability of commercial products, the preparation of them by NIH became less required.

One of the divisions of Central Virus Diagnostic Laboratory is National and WHO Serum Reference Bank, whose assigned activities are (1) acceptance and storage of selected collections of sera and of data in a retrievable form, (2) investigation of sera, (3) processing of data with a computer, and (4) providing consultation and advice to national health services on immunological surveys. Other virus departments of NIH have been co-operating with this laboratory in their respective fields.

As for the reference activity in bacteriology, NIH has not yet a specialized department. However, the First Department of Bacteriology has been performing such activities at least in some particular subjects (Tables XII and XIII). The department has long been the center for the taxonomy of enterobacteriaceae, especially being well-known internationally for Salmonella and Vibrios (Tables XIV-XIX). Phage typing of $S$. typhi isolates has also been an important duty of the department, contributing greatly to local health administration by providing the epidemiological information of the disease. In recent years, the isolates sent to this department from DPHLs cover around $80 \%$ of the notified cases of typhoid fever (Tables XVIII and XIX). The Second Department of Bacteriology has been responsible for the services in identification of anaerobic bacteria and leptospira, and Department of Tuberculosis has been so in identification of mycobacterial species including phage types.

The Institute of Public Health (IPH): The Institute of Public Health was established in 1938 in Tokyo as the government (MHW)-affiliated institute for training public health personnels at post-graduate level and performing research work in various fields of public health. The building and equipments of the institute were donated by the Rockefeller foundation.

Though the system of training courses has been subjected to occasional changes in the past 40 years, IPH has now four different courses. The 3-year research course leading to Diploma of Doctorate in Public Health is offered to the graduates of medical and dental-schools, or those who have master's degrees of qualified schools, still or the equivalents. The 2-year course is offered to the medical and dental graduates, or those who have a bachelor's degrees of various sciences related to public health. Three one-year courses (environmental sanitation, nursing, and health) are also offered to those of the above qualification. Finally, there are totally 13 special one-month courses intended to provide broader and new knowledge and techniques in the respective areas of 
work to those who are already in service.

As far as communicable diseases are concerned, most courses have curricula of epidemiology, communicable disease control, and food sanitation. Especially, the special course for public health microbiology has been playing a major role in refreshing laboratory techniques of the workers in DPHLs and health centers and in transmitting them the new knowledge required for their responsibilities in service. This course changes its main thema every year; e.g., virology, leptospirosis and venereal diseases for 1974, immunology, tuberculosis and mycology for 1975, and medical zoology and bacteriology for 1976. This type of training is so-called "full-time course", since training students have no responsibility other than to attend the laboratory course as learners of practical methods and their theoretical background. In this respect, it is different from the aforementioned training system in NIH where learners are usually trained in-service or under an apprenticeship system without a programmed course.

National Institute of Hygienic Sciences (NIHS): This institute experienced the longest history, about 100 years, among the $\mathrm{MHW}$-affiliated national institutes. It was established as a drug-control laboratory in Tokyo. However, it might be interesting to note that the national necessity of this kind of laboratory was first acknowledged in Japan in connection with the prevention of infectious diseases. Hence, in 1877, phenol for disinfection was manufactured from coal tar for the prevention of cholera prevalence. This was the first experience of drug production by a European process. Because of this historical fact, this institute is still called by the Japanese name of "Eisei Shikenjo (Hygiene Laboratory)."

NIHS has presently one administrative office, one library, 12 research divisions, one center (Biological Safety Research Center), one branch, and five experimental stations. The work of the institute may be classified into four groups; (1) drugs and cosmetics, (2) food and food additives, (3) environmental sanitation and hot spring, (4) pharmacology, toxicology, and microbiology related to the above-mentioned (1) to (3).

The Division of Microbiology of NIHS is mainly concerned with microbiological services for the quality control of drugs and foods, not only of domestic products but also of imported goods. Though Staphylococci, Cholera vibrio, $E$. coli, and Salmonella are the species most commonly treated here, the study on molds and their metabolites is a unique activity in the division. The sterility test of iv injections is also an important service.

\section{Private Laboratories}

Since 1957, private laboratories have been established one after another by local medical associations to perform laboratory tests asked by member physicians. This may correspond to the hospital laboratory in the character. There are now around 180 of such in the whole country. In addition, we have nearly 300 registered hygienic laboratories serving not only private clinics but also 


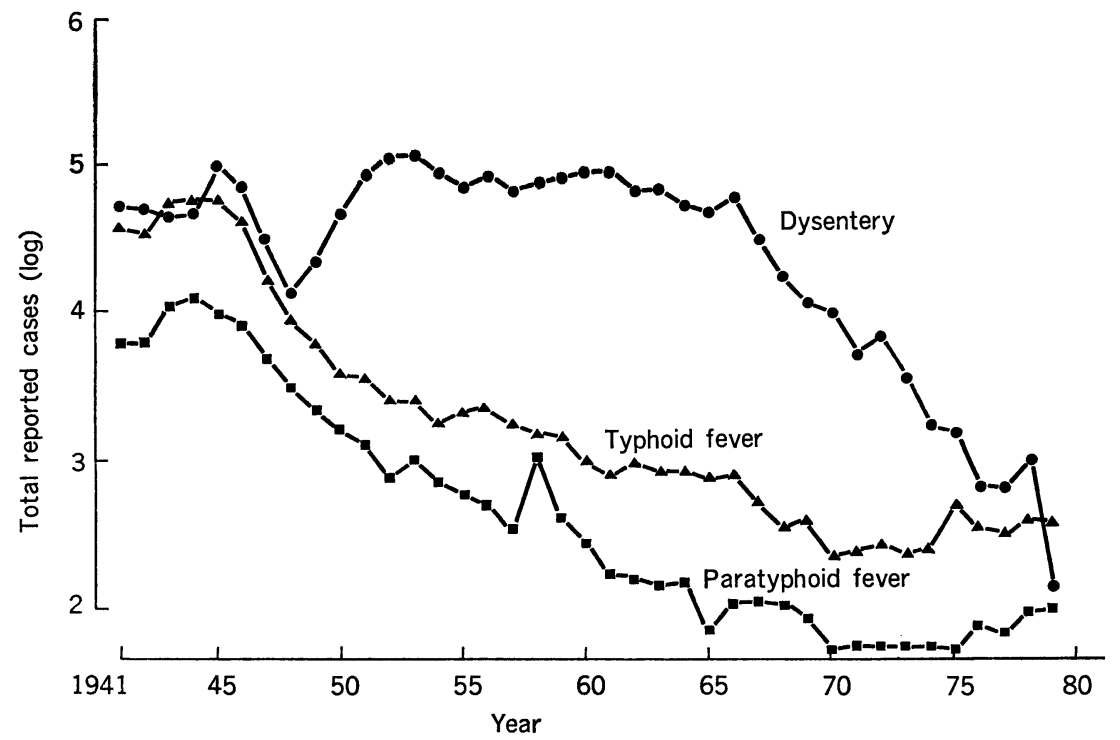

Fig. 6. Incidences of dysentery typhoid fever, and paratyphoid fever in Japan, 1941-1979. (National Survey of Mortality and Morbidity)

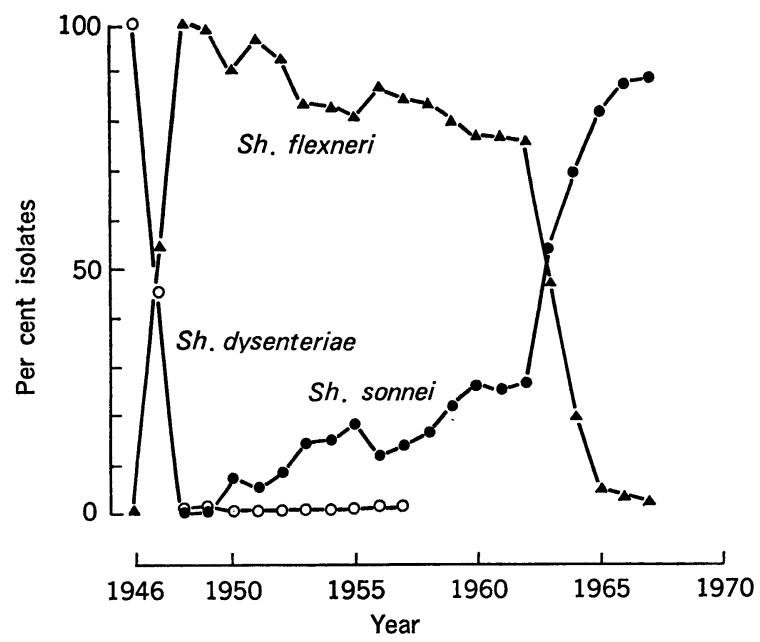

Fig. 7. The annual change of per cent isolates of Shigella subgroups as revealed by the survey in Niigata prefecture (Sasakawa).

environmental health. Microbiological tests are of course a part of the services of these private laboratories.

In this respect, the co-operation between DPHLs and the private laboratories is sometimes possible including personnel recruitment. However, the 


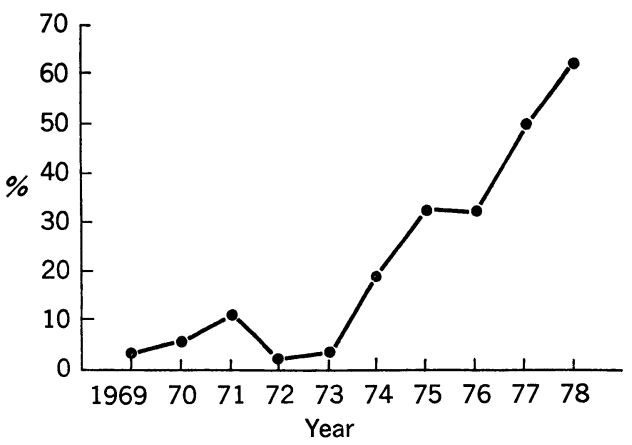

Fig. 8. Annual change of per cent imported strains in the total Shigella isolates. (Saito and Totani, 1980)

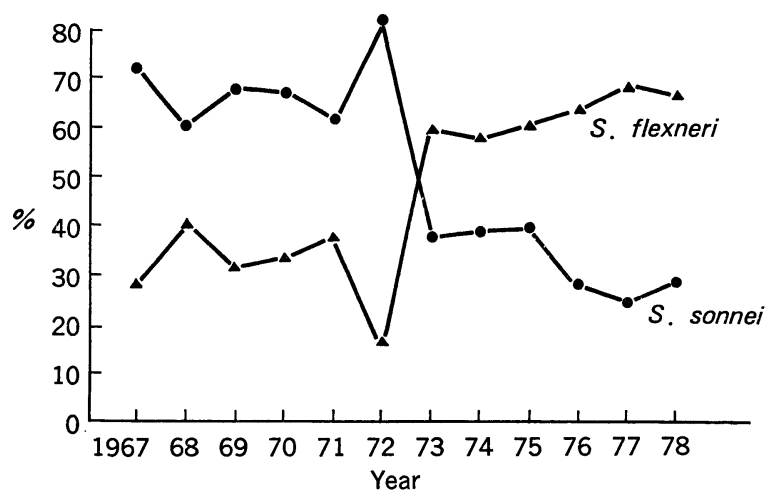

Fig. 9. Annual change of per cent isolates of Shigella subgroups in municipal hospitals for infectious diseases (Increase of S. flexneri due to imported cases). (Saito and Totani, 1980)

formal integration of them into the national network of PHLS is not practicable at present.

On the other hand, we have a private nation-wide system of PHLS run by a side organization of the Japan Anti-parasitosis Association. Testing work in this organization covers a wide range of clinical pathology, X-ray examination, and environmental hygiene. As for microbiological tests, the majority are concerned with culture of enterobacteria, especially from specimens of restaurant employees, food-factory employees, school children who are going on an excursion, etc. Salmonella species are the most frequent isolates. Sputum culture for acid-fast bacilli and drug-sensitivity tests of both general bacteria and mycobacteria are also the important work. Other main work is serological tests for the diagnosis of bacterial and viral infections as well as syphilis serology.

\section{The Surveillance System of Infectious Diseases in Japan}

The surveillance system of infectious diseases is organized by two lines of 


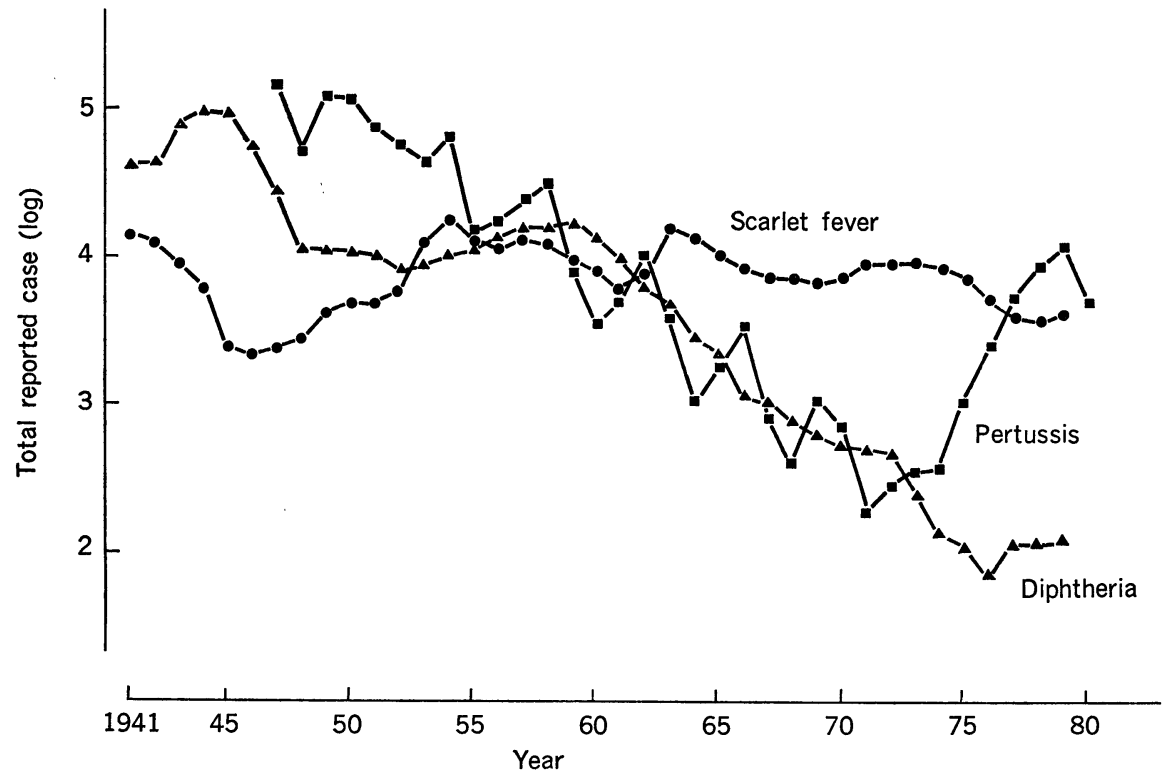

Fig. 10. Incidences of scarlet fever, pertussis, and diphtheria in Japan, 1941-1979. (National Survey of Mortality and Morbidity)

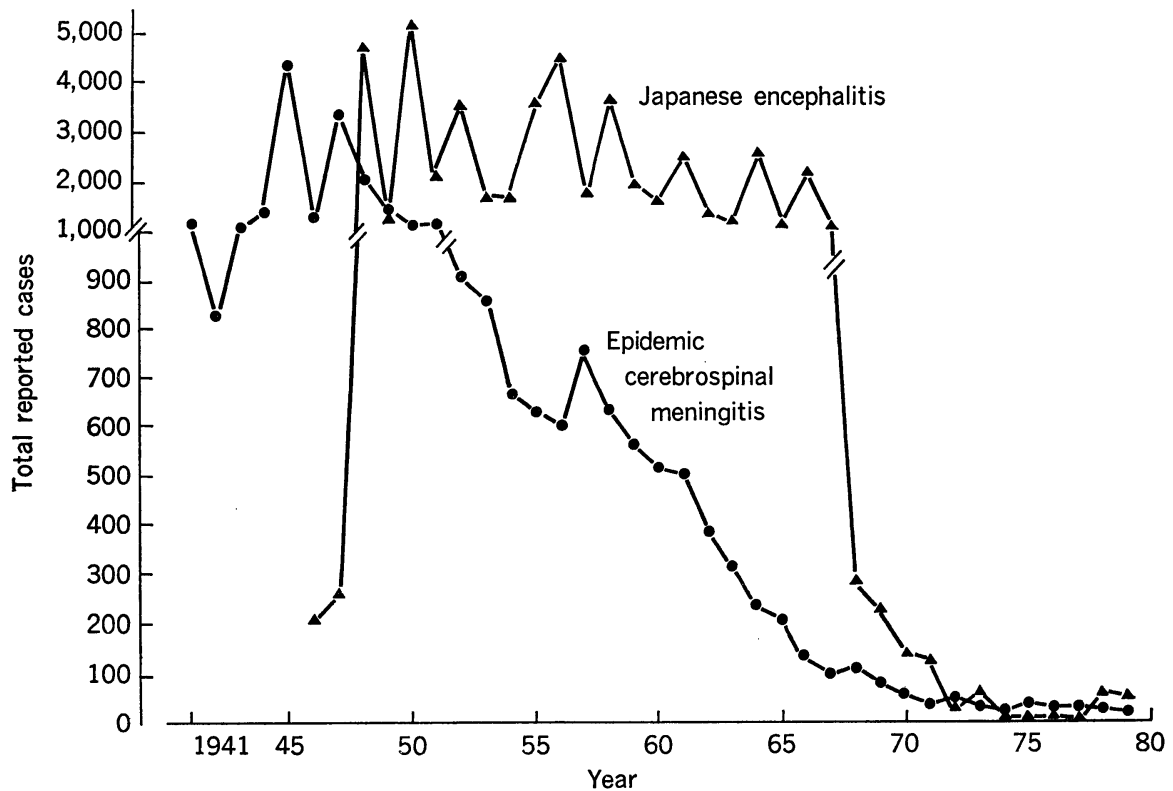

Fig. 11. Incidences of epidemic cerebrospinal meningitis and Japanese encephalitis in Japan, 1941-1979.

(National Survey of Mortality and Morbidity) 


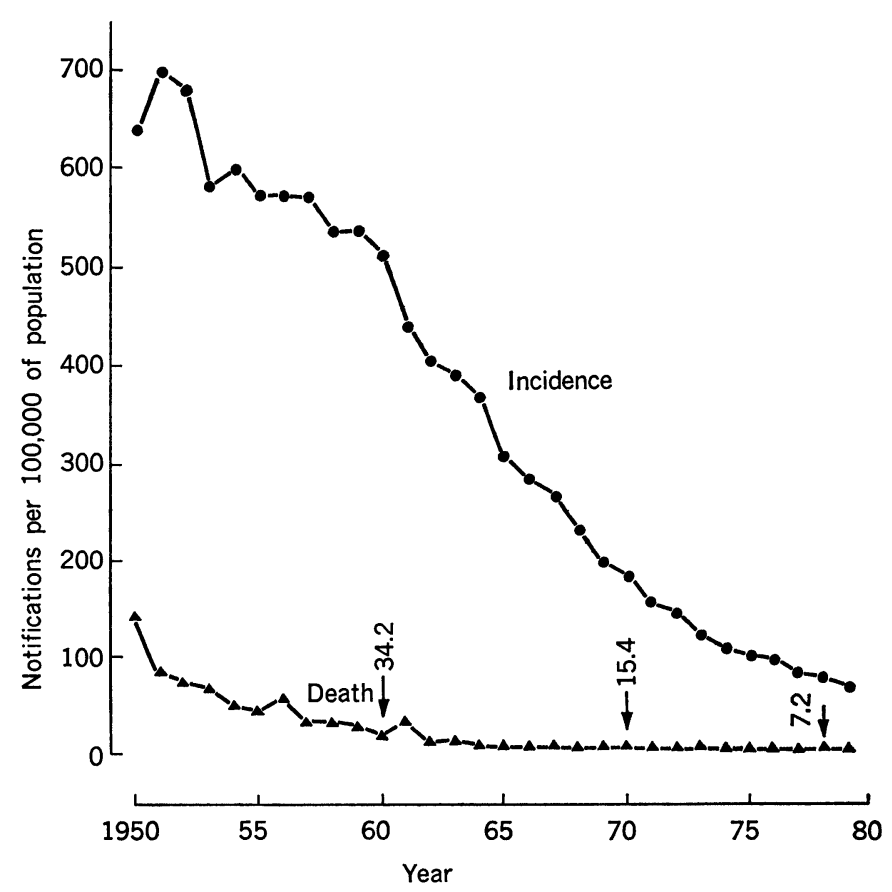

Fig. 12. Incidences and deaths from tuberculosis per 100,000 of population in Japan, 19501979.

(National Survey of Mortality and Morbidity)

information collection, one being case notification and the other being laboratory information. As will be described in Addenda, the laws of four country define 26 infectious diseases and food-poisoning as the notifiable diseases. The cases are reported to MHW through the route of physician-health center-district health agency, and summed up by Statistics and Information Department of MHW. In addition, when infectious diseases other than the notifiable ones become a problem of public health importance, an emergency system is set up to collect the necessary information to the Communicable Disease Surveillance Division of MHW.

As for laboratory information, however, we have had no regular and comprehensive system at the national level. Only with some particular subjects, e.g., phage typing of typhoid bacilli, we have a national network established on the agreement between DPHLs and NIH. This has been a voluntary research project without special budgetary provision from the national government. We also have another project which is generally called "Outbreak Forecast Project of Infectious Diseases". This surveillance system was established in 1962 for some specified diseases as a joint project between MHW and some co-operator prefectural governments. The main objective of this project is to survey the antibody level in the community through the field study conducted in one or 


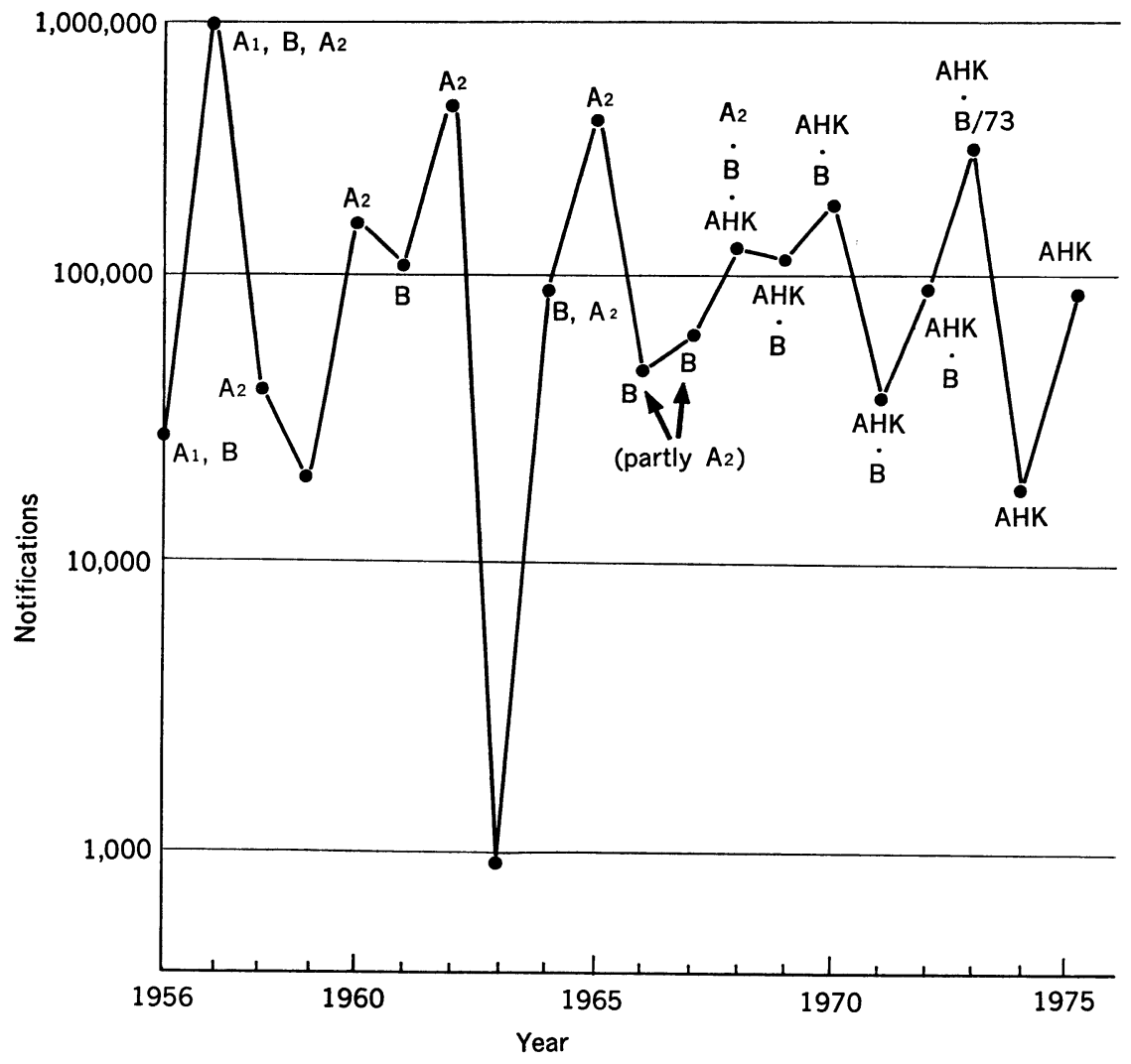

Fig. 13. Annual change of reported influenza cases.

(National Survey of Mortality and Morbidity)

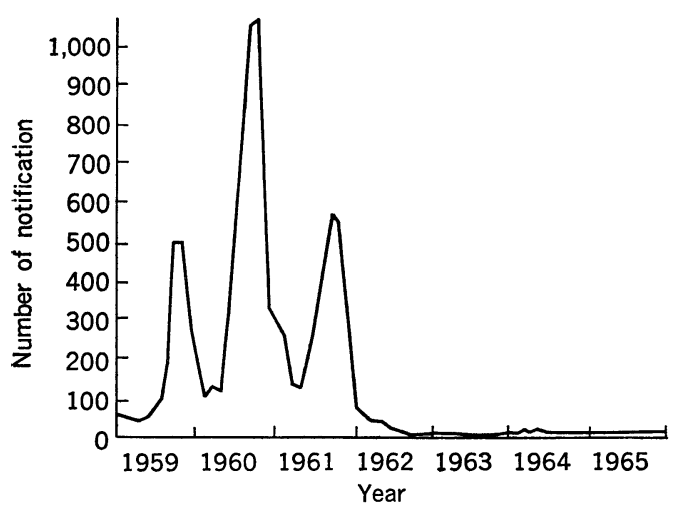

Fig. 14. Polio-"eradication" in Japan by mass-vaccination since 1961. (National Survey of Mortality and Morbidity) 


\section{TABLE XXII}

Incidences of three quarantinable diseases (cholera, plague, and smallpox) and typhus in Japan since 1900

\begin{tabular}{rrrrr}
\hline \multirow{2}{*}{ Period } & \multicolumn{4}{c}{ Number of reported cases } \\
\cline { 2 - 5 } & Cholera & Plague & Smallpox & Typhus \\
\hline $1900-1910$ & 21,003 & 2,406 & 21,319 & 184 \\
$1911-1910$ & 19,347 & 258 & 14,898 & 9,153 \\
$1921-1930$ & 1,633 & 136 & 8,074 & 304 \\
$1931-1940$ & 79 & 0 & 2,326 & 120 \\
$1941-1950$ & 1,245 & 0 & 22,004 & 42,959 \\
$1951-1960$ & 0 & 0 & 97 & 20 \\
$1961-1970$ & 3 & 0 & 0 & 0 \\
$1970-1979$ & 94 & 0 & 2 & 0 \\
\hline
\end{tabular}

National Survey of Mortality and Morbidity

\section{TABLE XXIII}

Incidences of four infectious diseases (malaria, tetanus, tsutsugamushi disease, and measles) in Japan in the last 5 years

\begin{tabular}{ccccc}
\hline & \multicolumn{4}{c}{ Number of notifications } \\
\cline { 2 - 5 } Year & Malaria & Tetanus & $\begin{array}{c}\text { Tsutsugamushi- } \\
\text { disease }\end{array}$ & Measles \\
\hline 1950 & 30 & 103 & 12 & 15,212 \\
1951 & 24 & 90 & 31 & 31,647 \\
1952 & 37 & 72 & 39 & 18,061 \\
1953 & 22 & 71 & 48 & 34,300 \\
1954 & 23 & 58 & 80 & 18,864 \\
\hline
\end{tabular}

National Survey of Mortality and Morbidity

two areas sampled in each prefecture, namely the survey of community immunity. On the basis of collected data, the national government is expected to foresee the possible future epidemic and to make the plan of counter-measure including vaccine production and vaccination. Laboratory work is conducted by DPHLs and NIH. The statistics are done by the Communicable Disease Surveillance Division of MHW and National Serum Reference Bank in NIH. The infectious diseases under this surveillance have long been polio, diphtheria, influenza, Japanese encephalitis and rubella. Then pertussis and measles have been included since 1976 and 1978, respectively.

In 1979, a new system for integrating laboratory information was organized as a 3-year pilot study with a research fund from MHW (Miyamura, 1980). In this system, NIH receives and computerizes the monthly records of isolates of pathogenic bacteria and viruses sent from each DPHL, and the summed data are returned monthly with some comments and directions. The first issue of this monthly report was published in January, 1980. This project is now going 


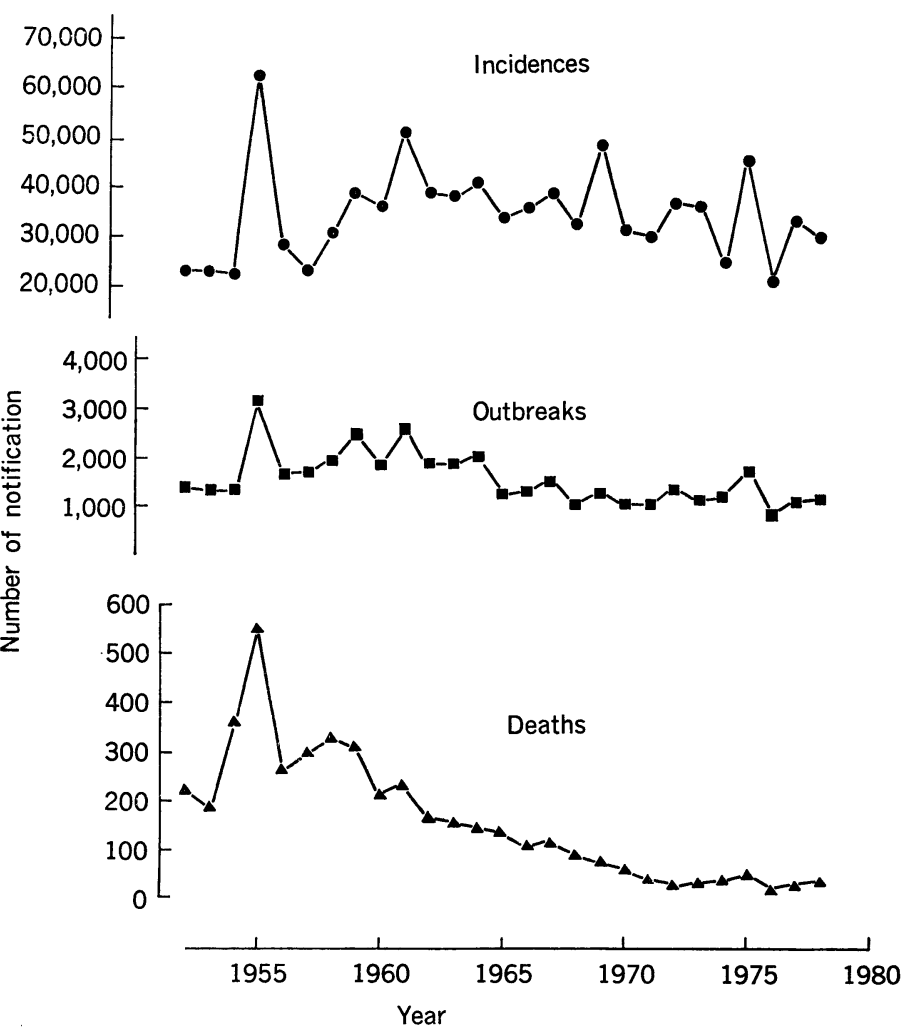

Fig. 15. Food poisoning in Japan, 1952-1978.

(National Survey of Mortality and Morbidity)

\section{TABLE XXIV}

Food poisoning (total 1,271 outbreaks) in Japan, in reference to causative foods and etiologic agents, 1978

Causative foods identified (839 outbreaks)

Etiologic agents identified (941 outbreaks)

Bacteria .................................. 818

Chemicals .................................. 7

Fish toxins (mostly tetrodo toxin) ….... 48

Plant toxins (poisonous mushrooms) ….. 68

Food Sanitation Division, Environmental Health Program, MHW 
TABLE XXV

Food poisoning in three districts of Japan in 1979 (Sakazaki et al., 1978)

\begin{tabular}{|c|c|c|c|}
\hline District & Etiologic agent & Outbreak & Case \\
\hline \multirow[t]{8}{*}{ Kanagawa } & Bacteria & & \\
\hline & Vibrio parahemoliticus & 21 & 270 \\
\hline & Staphylococcus aureus & 20 & 301 \\
\hline & Salmonella & 4 & 14 \\
\hline & Not identified & 4 & 235 \\
\hline & Natural toxins & & \\
\hline & Plant origin & 3 & 12 \\
\hline & Total & 52 & 832 \\
\hline \multirow[t]{9}{*}{ Shizuoka } & Bacteria & & \\
\hline & Vibrio parahemoliticus & $18(1)$ & $430(15)$ \\
\hline & Staphylococcus aureus & 3 & 86 \\
\hline & Salmonella & 4 & 152 \\
\hline & Pathogenic E. coli & 1 & 15 \\
\hline & Not identified & 11 & 433 \\
\hline & Natural toxins & & \\
\hline & Animal origin & 1 & 1 \\
\hline & Total & 38 & 1,117 \\
\hline \multirow[t]{10}{*}{ Tokyo } & Bacteria & & \\
\hline & Staphylococcus aureus & 38 & 393 \\
\hline & Vibrio parahemolyticus & 37 & 410 \\
\hline & Salmonella & 11 & 213 \\
\hline & Clostridium welchii & 3 & 527 \\
\hline & Bacillus cereus & 2 & 4 \\
\hline & Pathogenic E. coli & 1 & 1,213 \\
\hline & Not identified & 40 & 828 \\
\hline & Natural toxins & 3 & 18 \\
\hline & Total & 135 & 3,606 \\
\hline
\end{tabular}

to develop into a regular governmental project of surveillance for 18 nominated diseases. The plan at this moment indicates that 40 observation posts, mostly hospitals and clinics, are placed in each prefecture and municipality for the surveillance of case occurrence, and around 15 of them are expected to be a station to collect and forward specimens for laboratory tests to DPHLs through health centers. DPHLs are to be in close contact with those 15 laboratories and function as local reference laboratories. All the case and laboratory data are collected by district information centers and forwarded to the central information center (the Communicable Disease Surveillance Division of MHW) to be subjected to analysis and evaluation by a committee composed of specialists. At the same time, a feedback system will be organized which returns weekly the analyzed data back to the local medical associations, the local committee of education, villages and townships, etc. 
The 18 diseases as surveillance objects are pertussis, hemolytic streptococcal infection, atypical pneumonia, measles, mumps, aseptic meningitis, acute encephalitis, winter vomiting diarrhea of infants (viral gastroenteritis B), infectious diarrhea (viral gastroenteritis A), hand, foot and mouth disease (vesicular stomatitis with exanthem), erythema infection (fifth disease), exanthem subitum, herpangina, pharyngoconjunctivitis, epidemic keratoconjunctivitis, and acute hemorrhagic keratoconjunctivitis.

\section{AdDENDA}

1) The legal basis for communicable disease control: The communicable disease control in Japan has been conducted with the support of several laws. One of them is the Infectious Disease Prevention Law enacted in 1897, which provides the obligation of physicians to report, isolation of patients, disinfection of infected areas, and other necessary procedures taken by national and local health authorities to prevent the spread of the following 11 diseases; cholera, dysentery, typhoid fever, paratyphoid fever, smallpox, epidemic typhus, scarlet fever, diphtheria, epidemic meningitis, plague, and Japanese encephalitis. In addition, the law defined other 12 diseases as the notifiable ones without compulsory isolation. They are influenza, rabies, anthrax, infectious diarrhea, whooping cough, measles, yellow fever, relapsing fever, tetanus, malaria, tsutsugamushi disease, and filariasis. Later, poliomyelitis (1959) and Lassa fever (1976) were registered as designated infectious diseases.

Japanese schistosomiasis and trachoma are also defined as the notifiable diseases according to Parasitosis Prevention Law enacted in 1931 and Trachoma Prevention Law enacted in 1919, respectively.

The tuberculosis control program is completely defined in the Tuberculosis Control Law enacted in 1951. The law provides the responsibility of national and prefectural health authorities in the health examination for case-finding, BCG vaccination, reporting and registration of new cases.

For the control of venereal diseases, the Venereal Disease Prevention Law was enacted in 1948 and some amendment was made in 1966, which facilitated the reporting procedure by simplifying the items to be described on patients by physicians, and made it obligatory for any man and woman entering matrimony to take the serological test for syphilis (STS).

The basic policy for leprosy control is provided in the Leprosy Prevention Law. The original one was promulgated in 1907 and was amended twice later. The current law provides not only the prevention of leprosy, medical care and promotion of welfare of leprosy patients, but also the financial assistance to needy families of hospitalized patients. In addition to these provisions, the program for leprosy has been greatly promoted by the patronage of the Imperial Family and the activities of religious and other voluntary groups.

Finally, we have the Preventive Vaccination Law (1948) and the Quarantine Law, which provide the enforcement of both regular and emergent immuni- 
zation and the foreign quarantine service for health, respectively. In accordance with the partially amended provision of the former law made in June 1976, the immunization is now required by law for smallpox, diphtheria, pertussis, poliomyelitis, measles, rubella, cholera, influenza, Japanese encephalitis, and Weils' disease. On the other hand, it effected no more requirements for typhoid fever, paratyphoid fever, epidemic typhus or plague. The quarantine latter law was enacted in 1951, and it was amended on 1st of January in response to the effectivation of International Health Registrations. Food Sanitation Law which was enacted in 1947 has been playing an important role in controlling not only food poisoning but also food-borne infectious diseases.

2) The annual changes of the notifiable communicable diseases in the past 30 years: Figures 6 to 15 and Tables XXI to XXV show the annual changes of the notifiable communicable diseases in the past 30 years. The trend we can seen in these figures and tables may be interpreted as the successful results of the infectious disease control program in Japan, in which PHLs has played an essential role. These figures and tables are prepared mostly from the mortality and morbidity data of the Statistics and Information Department of the Ministry of Health and Welfare, and also from Annual Reports of NIH from 1947 to 1979.

\section{REFERENCES}

KodAmA, I. (1968): The present status of public health laboratory system in Japan. Koshueisei (Public Health), 32, 208-214 (in Japanese).

Kokuritsu Yoboeisei Kenkyujo (National Institute of Health of Japan) (1949-1979): Annual Report, 1949 to 1979 (in Japanese).

Koнno, R. (1968): The present status of public health laboratory system in some foreign countries in comparison with Japan. Koshueisei (Public Health), 32, 225-231 (in Japanese).

Koseisho (Ministry of Health and Welfare) $(1964,1976)$ : About the strengthening of district public health laboratories. Notification from the Ministry of Health and Welfare, No. 125, issued on May 8, 1964, No. 173, issued on No. 10, 1976 (in Japanese).

Koseisho (Ministry of Health and Welfare) (1974): Health services in Japan, 1974.

Ministry of Health and Welfare (1977): Guide to Health and Welfare Services in Japan, 1977.

Mryamura, K. (1980): Surveillance system for infectious diseases in Japan. Modern Media, 26, 583-597 (in Japanese).

National Association of District Public Health Laboratories (1979): Report on the present status of services in district public health laboratories (in Japanese).

Sarto, M. ANd Totani, T. (1980): Clinical and epidemiological observation on enteritis due to imported infectious diseases. Media Circle, 25, 131-136 (in Japanese).

SAKAZAKI, R. (1978): Reference system, especially as seen in foreign countries. Japan. J. Bacteriol., 32, 378-382 (in Japanese).

Sakazaki, R., Sakai, S., Takizawa, K., Nakamura, T., Asakawa, Y., Kobayashi, H., Nakanishi, T., Yoshizaki, E., Tamura, K. And Shimada, T. (1978): Studies on etiologic agents and mechanism of food poisoning. Report of the Research Committee of the Ministry of Health and Welfare.

The Statistics and Information Department of the Ministry of Health and Welfare (1941-1979): Mortality and morbidity data (in Japanese).

World Health Organization (1957): The public health laboratory service. First report of the expert committee on health laboratory methods. Wld Hlth Org., Techn. Rep. Ser., No. 128.

World Health Organization (1962): Planning, organization and administration of a national health laboratory service. Third report of the expert committee on health laboratory services. Wld Hlth Org. Techn. Rep. Ser., No. 236.

World Health Organization (1972): The planning and organization of a health laboratory 
service. Firth report of the WHO expert committee on health laboratory services. Wld Hlth Org. Techn. Rep. Ser., No. 491.

World Health Organization Regional Office for the Western Pacific (1960): Report on the seminar on health laboratory services. Manila, Philippines, 5-16, December, 1960.

World Health Organization Regional Office for the Western Pacific (1972): Report on the second regional seminar on health laboratory services. Manila, Philippines, 5-15, December, 1972.

YanAGisAwA, K. (1977): The present status of the National Institute of Health in 1977, the thirtieth year since its foundation. Japan. J. Med. Sci. Biol., 30, 1-17. 